\title{
Coupled Biological and Abiotic Mechanisms Driving Carbonyl Sulfide Production in Soils
}

\author{
Laura K. Meredith ${ }^{1,2, *(1)}$, Kristin Boye ${ }^{2,3}$ (1) , Connor Youngerman ${ }^{1}$, Mary Whelan ${ }^{4}$ (i), \\ Jérôme Ogée ${ }^{5}{ }^{\mathbb{D}}$, Joana Sauze ${ }^{5}$ and Lisa Wingate ${ }^{5}$ \\ 1 School of Natural Resources and the Environment, University of Arizona, Tucson, AZ 85721, USA; \\ youngerman@email.arizona.edu \\ 2 Department of Earth System Science, Stanford University, Stanford, CA 94305, USA; \\ kboye@slac.stanford.edu \\ 3 Stanford Synchrotron Radiation Lightsource, SLAC National Laboratory, Menlo Park, CA 94025, USA \\ 4 Department of Global Change Ecology, Carnegie Institution for Science, Stanford, CA 94305, USA; \\ mary.whelan@gmail.com \\ 5 INRA, UMR 1391 ISPA, 33140 Villenave d'Ornon, France; jerome.ogee@inra.fr (J.O.); \\ joana.sauze@ecotron.cnrs.fr (J.S.); lisa.wingate@inra.fr (L.W.) \\ * Correspondence: laurameredith@email.arizona.edu; Tel.: +1-520-626-4213
}

Received: 26 April 2018; Accepted: 14 June 2018; Published: 21 June 2018

\begin{abstract}
Understanding soil production of the trace gas carbonyl sulfide (OCS) is key to its use as a tracer of ecosystem function. Underlying its application is the observation that vascular plants consume atmospheric OCS via their stomatal pores in proportion with $\mathrm{CO}_{2}$ photosynthesis and that soil fluxes of OCS are negligible in comparison. Recent soil-centered studies demonstrate that soils can produce OCS and contribute as much as a quarter of the atmospheric terrestrial flux. Despite the potential widespread importance of soil OCS emissions, insufficient data exist to predict variations in OCS production across ecosystems, and the chemical and biological drivers of OCS production are virtually unknown. In this study, we address this knowledge gap by investigating variables controlling OCS soil production including soil physical and chemical properties, microbial community composition, and sulfur speciation in two independent surveys. We found that soil OCS production was nearly ubiquitous across the 58 sites, increased exponentially with temperature, and was insensitive to visible light conditioning. Soil $\mathrm{pH}, \mathrm{N}$, and $\mathrm{C} / \mathrm{N}$ were predictors of OCS soil production rates in both soil surveys. Patterns in soil S speciation and predicted microbial S-cycling pathways both pointed to S-containing amino acids such as cysteine and methionine and their derivatives as potential precursors for OCS production. Elevated sulfate levels were associated with OCS production in some soils. This study provides new mechanistic insight into OCS production in soils and presents strategies to represent soil OCS fluxes that facilitate the use of OCS as a tracer for leaf-level processes related to carbon and water cycling.
\end{abstract}

Keywords: carbonyl sulfide; OCS; COS; sulfur cycle; soil; carbon cycle

\section{Introduction}

Soils may be either a source or sink of OCS, or both, and the conditions that dictate this balance are not well resolved. Maximum soil uptake of OCS is generally observed at intermediate moisture levels that support both gas diffusion and microbial activity, notably OCS hydrolysis by carbonic anhydrase (CA) [1]. Until recently, emissions of OCS by soils were thought to be a feature only of wetland systems (reviewed in [2]), but periods of net soil OCS emission have now been reported in forest, grassland, and cropland ecosystems [3-7]. Soil incubation studies have further shown that 
both OCS production and consumption are widespread in soils, and the balance of these two gross fluxes drives the net soil-atmosphere OCS exchange [8-10]. OCS production has also been observed from plant components (e.g., roots, non-photosynthetic plant tissues) [7,11] and non-vascular plants (e.g., liverwort, moss) [12,13]. The mechanism for OCS production and its sensitivity to environmental conditions are poorly understood, which limits efforts to account for OCS soil fluxes and represents a gap in our understanding of biosphere-atmosphere sulfur cycling. Process-level representation of soil OCS cycling is needed to reduce uncertainty in the global OCS budget. In addition, constraining spatial and temporal variability in soil-atmosphere OCS exchange will improve estimates of large-scale, leaf-level processes (e.g., stomatal conductance and photosynthetic $\mathrm{CO}_{2}$ uptake) derived from the application of OCS as an atmospheric tracer [14].

OCS production in soils could be driven by biological and/or abiotic processes, and divergent mechanisms have been proposed. Abiotic thermo- and photo-degradation reactions involving still unknown chemical and biological components or pathways may be a driver of OCS production $[8,11,13,15]$. Soil OCS production rates depend exponentially on temperature $[7,8,10]$, increase with light $[5,11]$, and persist at similar rates when the same soil sample is moist and dry [10]. Furthermore, OCS production persists in soils following biological inactivation by autoclaving $[11,16]$. These observations suggest an abiotic mechanism for OCS production such as photo-thermal degradation of sulfur compounds, which may be indirectly coupled to biological production of precursor compounds by soil microbes and plants. Additionally, some bacterial and fungal isolates emit OCS, though observations of OCS consumption are more frequent $[17,18]$. Known microbial metabolisms directly producing OCS include metabolism of carbon disulfide $\left(\mathrm{CS}_{2}\right)$ [19], thiocyanate $\left(\mathrm{SCN}^{-}\right)$[20-25], and isothiocyanate [26]. While enzymes associated with these production pathways have been described in some organisms (e.g., thiocyanate hydrolase [24]), their contributions to OCS soil fluxes have not been evaluated. New efforts are needed to identify the dominant mechanism(s) driving OCS production in soils.

Microbes participate in a wide array of $\mathrm{S}$ transformations in soil that may include the production of OCS precursors. Most sulfur in soils is contained in soil organic matter ( $>95 \%$ of total S) including microbial biomass $(\sim 1 \% \mathrm{~S})[27,28]$. Microbes mineralize organic $\mathrm{S}$ compounds to inorganic sulfate $\left(\mathrm{SO}_{4}{ }^{2-}\right)$, the bioavailable form for plant assimilation and for microbial assimilatory needs. Conversely, microbes carry out dissimilatory $\mathrm{S}$ redox reactions. For example, sulfate reducing bacteria and sulfur oxidizing bacteria gain energy through interconversions between sulfate $\left(\mathrm{SO}_{4}{ }^{2-}\right)$ and sulfide $\left(\mathrm{H}_{2} \mathrm{~S}\right)$, and their intermediates. As a result of these assimilatory and dissimilatory processes, soil systems contain a diverse spectrum of $S$ compounds that may serve as OCS precursors. A number of potential OCS precursors have been evaluated through soil amendments with mixed results. For example, cystine, cysteine, and thiocyanate amendments were found to stimulate OCS production in one study [29], while OCS production was only observed in response to thiocyanate addition but not to cysteine, methionine, sulfate, or elemental $\mathrm{S}$ in a second study [30]. Plants have been shown to release OCS as a result of the degradation of unstable S-containing intermediates such as aromatic isothiocyanates [31] and thiocarbamates [32]. The most extensive work on precursors to OCS production has been performed in aquatic systems, where OCS production has been observed from filtered natural water amended with disulfides (e.g., cystine), sulfides (e.g., methionine), thiols (e.g., cysteine), and thiocyanates (e.g., isothiocyanate) (Table 1) [33-36]. OCS production from aquatic systems has been found to depend on light (particularly UV light), oxygen levels, and the presence of dissolved organic matter, and proposed chemical mechanisms include photochemical degradation of S compounds [33,36-38] and light-independent reactions of sulfur radicals (thiyls) with carbonyl compounds [34,39]. A main challenge is to determine whether OCS production in different soils are related to one or more common microbial S-cycling pathway(s) and related S compound(s).

In this study, we investigate the role of physical, chemical, and microbial processes as drivers of OCS production in soils. Our aim was to determine whether common abiotic, biotic, or coupled abiotic-biotic processes dominate OCS production rates in different soils. Our approach was to 
collect soils from various locations, biomes, and land use types in two independent soil surveys that were conducted predominantly in the United States (Survey 1; 20 sites) and Europe (Survey 2; 38 sites). Net OCS fluxes were measured on air-dried soils, which reflect predominantly abiotic OCS production processes given that microbe-mediated OCS consumption ceases under moisture limitation [10]. To elucidate potential mechanisms, we measured the temperature (Survey 1) and light (Survey 2) sensitivity of OCS production in soils. Recognizing that many chemical, physical, and microbial factors operate and are coupled within the soil system, we characterized 75 properties in Survey 1 including $S$ and sulfate concentrations, $S$ speciation by $X$-ray absorption near edge structure (XANES) spectroscopy, and microbial community composition and 12 widely measured properties in Survey 2 that are useful for predictive models including soil C, N, $\mathrm{pH}$, and redox. In this paper, we analyze this extensive data set to address the following hypotheses: (1) the dominant production mechanism for OCS in soils is abiotic photo-thermal degradation of S compounds; (2) direct microbial OCS production pathways do not significantly contribute to OCS fluxes in soils; and (3) microbial and plant $S$ cycling indirectly drive OCS production in soils through production of $S$ intermediates. Our results will provide new mechanistic insight and predictive power for describing the production of OCS in soils.

Table 1. Previously reported OCS production from S species from aquatic systems (filtered natural water).

\begin{tabular}{ccccc}
\hline Compound & Classification & $\begin{array}{c}\text { Non-Photochemical } \\
\text { Production }\end{array}$ & $\begin{array}{c}\text { Photo-Chemical } \\
\text { Production (UV) }\end{array}$ & References \\
\hline Cysteine (CYS) & Thiol, R-SH & N & Y & {$[33,34,36,37,40]$} \\
\hline Methionine (MET) & $\begin{array}{c}\text { Thioether (organic } \\
\text { sulfide) R-S-R' }\end{array}$ & uncertain & {$[33,34,37]$} \\
\hline Glutathione (GSH) & Thiol, R-SH & Y & Y & {$[33,34]$} \\
\hline $\begin{array}{c}\text { 3-Mercaptopropionic acid } \\
\text { (3-MPA) }\end{array}$ & Thiol, R-SH & N & Y & {$[34]$} \\
\hline $\begin{array}{c}\text { Methyl mercaptan (MeSH) } \\
\text { Sulfide }\end{array}$ & Thiol, R-SH & N & Y & {$[34]$} \\
\hline $\begin{array}{c}\text { Dimeric disulfide } \\
\text { (Na-GSSG) }\end{array}$ & $\begin{array}{c}\text { Organic disulfide, } \\
\text { R-S-S-R' }\end{array}$ & N & Y & {$[34]$} \\
\hline $\begin{array}{c}\text { Methanesulfonic acid } \\
\text { (MSA) }\end{array}$ & Sulfonate, R-O-SO 2 & N & N & {$[34]$} \\
\hline
\end{tabular}

\section{Materials and Methods}

In this study, two separate surveys were conducted on soils of different origins, using similar methods that resulted in independent, yet complementary data sets. Survey 1 soils were part of an experiment designed to investigate the role of temperature in regulating OCS flux, while Survey 2 soils were used for experiments exploring the response of OCS to light. Differences and similarities between the survey methods are summarized in Table 2 and additional detail regarding the Survey 1 and 2 methods are described in $[8,41]$ and $[10,15]$, respectively.

\subsection{Soil Collection and Processing}

Soil samples were collected from the uppermost $10 \mathrm{~cm}$ (litter excluded) at 20 sites in Survey 1 and 38 sites in Survey 2 (Table 2) covering a range of biomes and land use types (Tables 2 and S1). Soils were sieved and used to determine field moisture and soil water holding capacity (WHC). Following sieving, soils were pre-treated in Survey 1 (Table 2) by transferring $80 \mathrm{~g}$ DW (soil dry weight) to sterilized half-pint mason jars, adjusting soil moisture levels with sterile nanopure water to $30 \%$ WHC, and incubating aerobically at $22.5^{\circ} \mathrm{C}$ for seven days in the dark. This pre-treatment was done for comparability to identical soil preparations in a separate, simultaneous study on the microbial drivers of OCS consumption in moist soils [41]. At 30\% WHC, soils are sufficiently moist to support microbial 
activity, but not so wet as to impede gas diffusion through the soil matrix [42]. The final treatment for both surveys involved transferring soils from either the 30\% WHC incubation pre-treatment (Survey 1) or the untreated field-moist soils (Survey 2) to aluminum trays to dry by evaporation. After air drying, soils were transferred to the gas flux measurement chambers to briefly acclimatize (Table 2), after which OCS and $\mathrm{CO}_{2}$ gas fluxes were measured on the dry soils.

Table 2. Side-by-side comparison of soil collection, processing, and analysis methods for Surveys 1 and 2.

\begin{tabular}{|c|c|c|}
\hline Soil Collection & Survey 1 & Survey 2 \\
\hline Sites & 20 & 38 \\
\hline Region & United States, Cambodia & Europe \\
\hline Biomes & $\begin{array}{l}\text { Arid, Mediterranean, Boreal, Temperate, } \\
\text { Tropical }\end{array}$ & Arid, Mediterranean, Boreal, Temperate \\
\hline Land use & Cropland, Desert, Grassland, Deciduous & Cropland, Orchard, Grassland, Deciduous \\
\hline Sampling depth & 0 to $10 \mathrm{~cm}$ (after removing litter) & 0 to $10 \mathrm{~cm}$ (after removing litter) \\
\hline Samples & 3 within a $1-m$ sampling radius & $3-5$ within $5-m$ radius \\
\hline Soil Processing & Survey 1 & Survey 2 \\
\hline Sampling depth & Replicates kept separate & Replicates homogenized \\
\hline Sieve mesh size & 2 mm (Humboldt Mfg., Elgin, IL, USA) & $5 \mathrm{~mm}$ \\
\hline Pre-treatment & $\begin{array}{l}\text { Air-dried } 3 \text { days, wet to } 30 \% \text { WHC, } \\
\text { incubated } 7 \text { days at } 22.5^{\circ} \mathrm{C} \text { in the dark }\end{array}$ & Soils at field moisture untreated \\
\hline Final treatment & Air-dried for a median of 45 days & Air-dried for 7-14 days \\
\hline Flux Measurements & Survey 1 & Survey 2 \\
\hline Soil amount & 80 g dry soil & 350-400 g dry soil \\
\hline Measurement chamber & $\begin{array}{l}\text { 1-L PFA chambers (100-1000-01, Savillex, } \\
\text { Eden Prairie, MN, USA). Surface area of } \\
0.0078 \mathrm{~m}^{2}\end{array}$ & $\begin{array}{l}0.825 \mathrm{~L} \text { glass jars with customized glass lid } \\
\text { with stainless steel and PTFE ports. Surface } \\
\text { area of } 0.0062 \mathrm{~m}^{2}\end{array}$ \\
\hline Acclimation & $24 \mathrm{~h}$ dark at $22.5^{\circ} \mathrm{C}$ & $\begin{array}{l}2-3 \text { days under } 12 \mathrm{~h} \text { dark } / 12 \mathrm{~h} \text { light } \\
\text { photoperiod at } 17^{\circ} \mathrm{C}\end{array}$ \\
\hline Treatments & $\begin{array}{l}\text { Temperature ramp }\left(11.5^{\circ} \mathrm{C} \text { to } 37.5^{\circ} \mathrm{C} \text {; }\right. \\
\text { dark only) }\end{array}$ & $\begin{array}{l}\text { Light conditioning and temperature artifact } \\
\text { (dark at } 17^{\circ} \mathrm{C} \text {; light at } 23^{\circ} \mathrm{C} \text { ) }\end{array}$ \\
\hline Inlet air source & $\begin{array}{l}\text { Room air passed through buffer volume } \\
\text { (2 L PFA chamber) }\end{array}$ & $\begin{array}{l}\text { Scrubbed ambient air with } \mathrm{CO}_{2} \text { and OCS } \\
\text { added to approximately } 420 \mathrm{ppm} \mathrm{CO}_{2} \text { and } \\
500 \mathrm{ppt} \text { OCS. }\end{array}$ \\
\hline Flow rate & $0.3 \mathrm{~L} \mathrm{~min}^{-1}$ & $0.25 \mathrm{~L} \mathrm{~min}^{-1}$ \\
\hline Temperature control & Water bath [8] & $\begin{array}{l}\text { Customized climate-control chamber } \\
\text { (MD1400, Snijders, Tillburg, } \\
\text { The Netherlands) }\end{array}$ \\
\hline Dynamic flow sequence & $\begin{array}{l}\text { Inlet ( } 10 \mathrm{~min}), \mathrm{N}_{2} \text { tank background } \\
(10 \mathrm{~min}) \text {, and outlet ( } 40 \mathrm{~min})\end{array}$ & Each component $2 \mathrm{~min}$ \\
\hline Time averaged & $\begin{array}{l}\text { Last } 4 \text { min inlet, } 4 \text { min for } \mathrm{N}_{2} \text {, and } 8 \text { min for } \\
\text { outlet measurements. }\end{array}$ & Last $20 \mathrm{~s}$ for all measurements. \\
\hline Soil Characterization & Survey 1 & Survey 2 \\
\hline $\begin{array}{l}\text { Measured properties } \\
\text { (pre-treatment) }\end{array}$ & $\begin{array}{l}\text { WHC, microbial biomass, microbial } \\
\text { community composition (DNA), } \\
\text { metatranscriptomes (RNA) }\end{array}$ & WHC, soil moisture \\
\hline $\begin{array}{l}\text { Measured properties } \\
\text { (final treatment) }\end{array}$ & $\begin{array}{l}\mathrm{OCS} \text { and } \mathrm{CO}_{2} \text { fluxes, } \mathrm{BD}, \mathrm{C}, \mathrm{N}, \mathrm{pH} \text {, texture, } \\
\text { soil moisture, } \mathrm{S} \text {, other elements, } \mathrm{SO}_{4} \text {, } \\
\text { XANES }\end{array}$ & $\begin{array}{l}\text { OCS and } \mathrm{CO}_{2} \text { fluxes, } \mathrm{BD}, \mathrm{C}, \mathrm{N}, \mathrm{pH} \text {, texture, } \\
\text { redox potential }\end{array}$ \\
\hline pH method & 1:2.5 soil-water ratio & 1:5 soil-water ratio \\
\hline Texture method & $\begin{array}{l}\text { Multi-wavelength laser diffraction particle } \\
\text { analyzer (LS } 13320 \text { MW, Beckman Coulter, } \\
\text { Brea, CA, USA) }\end{array}$ & $\begin{array}{l}\text { Sedimentation method (INRA method } \\
\text { SOL-0302). }\end{array}$ \\
\hline $\mathrm{C}$ and $\mathrm{N}$ method & $\begin{array}{l}\text { Elemental analyzer (NA-1500, Carlo-Erba, } \\
\text { Milan, Italy) }\end{array}$ & $\begin{array}{l}\text { Gas chromatography and catharometer } \\
\text { (corrected for } \mathrm{CaCO}_{3} \text {; INRA methods } \\
\text { NF-ISO-13878, NF-ISO-10694) }\end{array}$ \\
\hline $\begin{array}{l}\text { Microbial biomass } \\
\text { method }\end{array}$ & $\begin{array}{l}\text { Chloroform fumigation-potassium sulfate } \\
\text { extraction method [43] }\end{array}$ & $\begin{array}{l}\text { Chloroform fumigation-potassium sulfate } \\
\text { extraction method }[44,45] \text {. }\end{array}$ \\
\hline
\end{tabular}




\subsection{Trace Gas Flux Measurements}

\subsubsection{Trace Gas Flux Procedures and Calculations (Surveys 1 and 2)}

Measurement chambers containing air-dried soils were installed on dynamic flow-through systems for OCS exchange measurements. Soil-air gas exchange was determined from differences in OCS and $\mathrm{CO}_{2}$ mole fractions measured in chamber outlet and inlet air flowing using quantum cascade laser spectrometers at $1 \mathrm{~Hz}$ (QCLS, Aerodyne Research, Inc., Billerica, MA, USA for both surveys). The QCLS instrument precision is approximately 2 ppt for OCS at $60 \mathrm{~s}$ averaging with an absolute calibration accuracy of $5 \%$ for OCS (Aerodyne Research, Inc., Billerica, MA, USA). The measurement setups have been previously described in detail for Survey 1 [8] and Survey 2 [15]. Two modifications were made for Survey 1. Firstly, we modified the experimental setup of [8] to include a buffer volume (2 L PFA chamber) on the gas inlet line to dampen fluctuations in OCS mole fractions in inlet air from the laboratory. Secondly, we corrected OCS mole fraction measurements for water vapor dilution and spectral interferences $[8,46]$ using instrument-specific water vapor dependencies to adjust mole fractions to a common humidity level of $0.010 \mathrm{~mol} \mathrm{~mol}^{-1}$. The dependencies to water vapor mixing ratio $\left[\mathrm{H}_{2} \mathrm{O}\right]\left(\mathrm{mol} \mathrm{mol}^{-1}\right)$ was $[\mathrm{OCS}](\mathrm{ppb})=-1.05\left[\mathrm{H}_{2} \mathrm{O}\right]+0.539$. Water vapor corrections were $3 \%(5 \%)$ in the median (95th percentile).

Differences between mole fractions in the flow-through chamber inlet gas and outlet gas were measured along with zero tanks $\left(\mathrm{N}_{2}\right.$ tank) or calibration gases according to the dynamic flow sequenced used for each survey (Table 2). Instrument drift was corrected for using $\mathrm{N}_{2}$ background measurements. For both surveys, fluxes of OCS were determined from the difference between mole fractions at the outlet $\left(c_{o}\right)$ and inlet $\left(c_{i}\right)$ measured, respectively, by the chamber and bypass flow. For example:

$$
F=\frac{u}{S}\left(c_{o}-c_{i}\right)
$$

where $u\left(\mathrm{~mol} \mathrm{~s}^{-1}\right)$ is the flow rate of air through the chamber, $S$ is the soil surface area and $c_{o}$ and $c_{i}$ are the OCS mixing ratios inside the chamber and the bypass air, respectively. OCS production rates are not significantly different in dry and moist soils, and thus, OCS production rates can be determined from the net fluxes of OCS in air-dried soils in which biological OCS uptake is limited [10]. $\mathrm{CO}_{2}$ fluxes $\left(F_{\mathrm{CO} 2}\right)$ were simultaneously determined using Equation $(1)$ in both surveys.

\subsubsection{Temperature Response Experiment (Survey 1)}

Survey 1 fluxes were for each dry soil replicate over a $5{ }^{\circ} \mathrm{C}$ - or $10{ }^{\circ} \mathrm{C}$-step temperature ramp between $10{ }^{\circ} \mathrm{C}$ and $40^{\circ} \mathrm{C}$ at each temperature for three cycles of the aforementioned 60-min program (inlet, zero, outlet). Soil chambers were placed in a water bath for temperature control. OCS fluxes in the dry soils derived using Equation (1) are reported at $20{ }^{\circ} \mathrm{C}$ and $40{ }^{\circ} \mathrm{C}$ as $F_{20}$ and $F_{40}$, respectively. We fit measurements of the temperature-dependent emission of OCS from dry soils using a least-square fit to the exponential model.

$$
F_{\text {abiotic }}=\alpha \exp \left(\beta T_{\text {soil }}\right)
$$

where $T_{\text {soil }}$ is the soil temperature in ${ }^{\circ} \mathrm{C}, \alpha$ and $\beta$ represent the OCS flux at $0{ }^{\circ} \mathrm{C}$ and the temperature sensitivity of OCS emissions, respectively $[7,8]$. For consistency with previous work, results were reported in the commonly-used $Q_{10}$ framework [10,47],

$$
F_{\text {abiotic }}=P_{\text {ref }} Q_{10}\left(T_{\text {soil }}-T_{\text {ref }}\right) / 10
$$

where $T_{r e f}$ is a reference temperature, here taken to be $20{ }^{\circ} \mathrm{C}$, and $P_{\text {ref }}$ represents the OCS flux at $T_{r e f}$, and the temperature sensitivity terms are analytically related using the following expression: $Q_{10}=\exp (\beta \times 10)$. We accounted for differences between set $\left(10,15,20,25,30,35\right.$, and $\left.40{ }^{\circ} \mathrm{C}\right)$ and actual $\left(11.5,15.5,20.5,24.5,28.5,33.5\right.$, and $\left.37.5^{\circ} \mathrm{C}\right)$ soil temperature during the incubation. The mixing ratios inside the chamber were also converted into volumetric concentration using air temperature 
measurements in the chamber and assuming an atmospheric pressure of $101.325 \mathrm{kPa}$. OCS fluxes in desert samples were negative (indicating net uptake even when dry), but became less negative with temperature, indicating either less uptake or more production with increasing temperature (Figure S1), and we applied a zero offset before fitting with an exponential temperature response curve to determine temperature sensitivity parameters (offsets for UT-CR and UT-MO were $1.8 \mathrm{pmol} \mathrm{kg}^{-1} \mathrm{~min}^{-1}$ and $0.6 \mathrm{pmol} \mathrm{kg} \mathrm{min}^{-1}$, respectively). We adjusted Survey 1 fluxes from $20.5^{\circ} \mathrm{C}$ to $17^{\circ} \mathrm{C}$ using the observed temperature sensitivity for each soil (Equation (2)) to match the conditions of Survey 2 dark fluxes for plotting purposes only (negative fluxes were not adjusted). All other analyses of $F_{20}$ are performed on unadjusted flux measurements at $20.5^{\circ} \mathrm{C}$ for Survey 1 and $17^{\circ} \mathrm{C}$ for Survey 2 .

\subsubsection{Light Response Experiment (Survey 2)}

Soil OCS production rates $\left(F_{20}\right)$ were measured in the dark and under visible light $(400-700 \mathrm{~nm}$; $500 \mathrm{~mol}$ (photons) $\mathrm{m}^{-2} \mathrm{~s}^{-1}$ ) on dry soils. The dark treatment soil microcosms were covered with aluminum foil and were thermally-regulated at $17^{\circ} \mathrm{C}$. Those that received light were slightly warmer, typically around $23^{\circ} \mathrm{C}$ because the light treatment caused a heating artifact [13,15]. This temperature difference was measured during the incubations with stainless temperature probe (three-wire PT100) that measured the temperature of the soil surface at $2-4 \mathrm{~cm}$ depth. $Q_{10}$ was not determined in Survey 2 under light or dark conditions, therefore we did not attempt adjust $F_{20}$ values (light or dark) to a common temperature for a comparison of light conditioning effects under constant temperature conditions.

\subsection{Soil Characterization}

\subsubsection{Soil Physical, Chemical, and Microbial Community Characterization (Surveys 1 and 2)}

Soil characterization performed in both surveys included soil moisture, WHC, bulk density (BD), texture, $\mathrm{pH}, \mathrm{C}$, and $\mathrm{N}$ following methods detailed in Table 2. Additional information on Survey 1 and Survey 2 methods can be found in [8,41] and [10,15], respectively. Gravimetric $\left(\mathrm{g} \mathrm{H}_{2} \mathrm{O} \mathrm{g}^{-1}\right.$ soil) water holding capacity (WHC) was determined from the mass difference before and after $48 \mathrm{~h}$ of $105^{\circ} \mathrm{C}$ drying of soils saturated ( $20 \mathrm{~g}$ soil in $40 \mathrm{~mL}$ nanopure water) for $2 \mathrm{~h}$ in stoppered filter funnels (Whatman no. 42, GE Healthcare, Little Chalfont, UK) and then drained for $6 \mathrm{~h}$ [48]. Bulk density (BD) was determined from soil mass (10 g) and volume (measured in $15 \mathrm{~mL}$ conical tubes). We report soil moisture as the gravimetric $(G W C ; \mathrm{m} / \mathrm{m})$ or volumetric water content $(\mathrm{VWC} ; v / v)$ from the mass difference before and after $48 \mathrm{~h}$ of $105^{\circ} \mathrm{C}$ drying (volume conversion with BD). Soil texture is reported in as the particle distribution of clay $(<2 \mu \mathrm{m})$, silt $(2 \mu \mathrm{m}$ to $50 \mu \mathrm{m})$, and sand $(>50 \mu \mathrm{m})$ was determined by laser diffraction (Survey 1 ) and sedimentation (Survey 2) methods, and are reported here on the sedimentation scale for comparability [49]. Soil $\mathrm{pH}, \mathrm{C}$, and $\mathrm{N}$ were analyzed on dry soils in both surveys. Survey 2 soils were analyzed for redox potential using the same slurry as for $\mathrm{pH}$. Climatic data were derived from 30-year averages (1984-2014) of Climate Research Unit (CRU TS v3.25) data [50].

\subsubsection{Soil S Speciation (Survey 1)}

We characterized soil S speciation in Survey 1 soils. Directly after the dynamic flux measurement, dry soils were destructively sampled to determine total sulfur, sulfate, and XANES analyses. Elements, including S, were measured by X-ray diffraction spectrometry (Xepos HE XRF Spectrometer, Spectro Analytical Instruments $\mathrm{GmbH}$, Kleve, Germany). Sulfate was measured by ion chromatography (IC) in wet and dry soils (DX-500, Dionex, Thermo Scientific, Waltham, MA, USA) following potassium phosphate $\left(0.016 \mathrm{M} \mathrm{KH}_{2} \mathrm{PO}_{4}\right)$ or deionized water extractions (1:5 soil to solution, $2 \mathrm{~h}$ shaking, centrifuged, filtered $0.2 \mu \mathrm{m}$ ) for total and soluble inorganic sulfate, respectively, thus revealing adsorbed sulfate by difference. 
S K-edge XANES spectroscopy identifies the oxidation state and co-ordination environment of soil sulfur by comparison against spectral libraries of known reference compounds [51]. We performed sulfur K-edge XANES (X-ray absorption near-edge structure) spectroscopy on a few milligrams of dry soil under He-atmosphere at beamline 4-3, Stanford Synchrotron Radiation Lightsource (SSRL), using a $\mathrm{Si}(111)$ monochromator (energy calibrated by setting the first edge of the in-line thiosulfate standard to $2472.02 \mathrm{eV}$ ) and SiLi Vortex detector. Normalized sample spectra were fit with linear combination fitting using Athena software (Demeter 0.9.25, using Ifeffit 1.2.12) [52] and model spectra from the sulfur XANES spectra database (http:/ / www.esrf.eu/home/UsersAndScience/Experiments/ XNP/ID21/php.html) provided by the ID21 beamline at the European Synchrotron Radiation Facility. Species with $<2 \%$ contribution to the fits were disregarded.

\subsubsection{Soil Microbial Characterization (Survey 1)}

Microbial biomass, community composition, and metatranscriptomes were analyzed in Survey 1 soils. Soil samples were taken at the end of the 'moist' pre-treatment (Table 2) and were preserved for DNA- (flash-frozen in liquid nitrogen) and RNA- (LifeGuard ${ }^{\circledR}$ Soil Preservation Solution, MO BIO Laboratories, San Diego, CA, USA) based analyses. Soil DNA was later extracted from $0.25 \mathrm{~g}$ of each replicate (PowerSoil ${ }^{\circledR}$ DNA Isolation Kit, MO BIO Laboratories, San Diego, CA, USA) and RNA was extracted (PowerSoil ${ }^{\circledR}$ RNA Isolation Kit, MO BIO) from $1.0 \mathrm{~g}$ of one replicate of ten sites (Table A1). Phylogenetic amplicon iTag DNA sequencing from DNA extract with 16S rRNA (V4) and fungal ITS2 (ITS9F/ITS4R) primers and metatranscriptome sequencing from soil RNA were performed by the Department of Energy Joint Genome Institute (JGI), Walnut Creek, CA, USA. Data sets are available in the JGI Genome Portal (https:/ / genome.jgi.doe.gov/) under JGI proposal ID 2033. Sequence data were collected from the moist-soil pre-treatments, and the patterns in microbial community composition and biomass (and certainly gene expression) may have shifted over the ca. 45-day air dry treatment in uncharacterized ways.

Soils were sampled following the Survey 1 pretreatment for microbial biomass, which was determined by chloroform fumigation of $3 \mathrm{~g}$ DW for three days in the dark following [43-45]. Specifically, fumigated and non-fumigated soils were extracted with $10 \mathrm{~mL} 0.5 \mathrm{~K}_{2} \mathrm{SO}_{4}$ through pre-leached (using $0.5 \mathrm{M} \mathrm{K}_{2} \mathrm{SO}_{4}$ ) filter paper (Whatman no. 1, GE Healthcare, Little Chalfont, UK) after one hour of vigorous shaking. Extracts were frozen until dilution (1:3 into DI water) and analysis made on a total organic carbon analyzer (TOC-L, Shimadzu, Tokyo, Japan). The chloroform-labile pool of $\mathrm{C}$ or $\mathrm{N}$ ( $\mathrm{EC}$ and $\mathrm{EN}$; ug $\mathrm{C}$ or ug $\mathrm{N} \mathrm{g} \mathrm{DW}^{-1}$ ) was estimated from the difference between the extracted $\mathrm{C}$ or $\mathrm{N}$ in fumigated and control samples and converted to microbial biomass (C or $\mathrm{N}$ ) using microbial $\mathrm{C}=\mathrm{EC} / k_{E C}$ or microbial $\mathrm{N}=\mathrm{EN} / k_{E N}$, where $k_{E C}$ and $k_{E N}$ represent the microbial $\mathrm{C}$ and $\mathrm{N}$ mineralization efficiency, taken here to be the constants 0.45 and 0.54 , respectively $[44,53]$.

\subsection{Data Analysis}

\subsubsection{Predicting Microbial Pathways from Composition and Gene Expression Data}

We predicted phenotypes and organism-level functional pathways related to sulfur cycling from Survey 1 microbial community composition using the BugBase algorithm and online analysis tool [54] that draws from other software [55-60]. We used the BugBase default threshold-finding feature on non-rarified OTU tables to predict pathway abundance in each site. Putative thiocyanate hydrolase $(\operatorname{scn} C)$ genes were recovered from Survey 1 soil metatranscriptomes using the IMG/MER [58] with the following search tools: (1) function search for nitrile hydrolase (pfam02979), which demonstrates significant homologies with scnC [61]; and (2) BLAST search with Thiobacillus thioparus DSM 505 scnC amino acid sequence (Joint Genome Institute Integrated Microbial Genomes Gene ID 2515447191) as the query (blastp, $1 \times 10^{-15}$ threshold). 


\subsubsection{Statistical Tests and Multivariate Data Analysis}

All analyses were done with $\mathrm{R}$ version 3.3.3 (R Core Team 2017). The effect of biome, land use, and conditioning (i.e., flux measurements taken in the dark or light) on the OCS flux at $20{ }^{\circ} \mathrm{C}\left(F_{20}\right)$ and $40{ }^{\circ} \mathrm{C}\left(F_{40}\right)$, and $Q_{10}$, was evaluated with linear models and ANOVAs. Least squared means (R package lsmeans) was used to determine the difference in mean of $F_{20}, F_{40}$, and $Q_{10}$; significant differences of means $(p \leq 0.05)$ were determined using Tukey's adjustment. Survey 1 flux data was log transformed to meet the assumptions of normality and equal variance; data were back-transformed for interpretation.

A series of partial least square regression (PLSR) models were evaluated ( $R$ package plsdepot). PLSR is a type of multivariate analysis that combines features of principal components analysis (PCA) and multiple regression, and can be used to analyze a set of dependent variables from a large set of independent variables [62]. The PLSR algorithm extracts orthogonal linear combinations of the independent variables into components that account for the greatest variation in the response variable. We determined the properties of soils that were drivers of observed fluxes by assessing the magnitude of squared weights of all variables within the first two components of each PLSR model [63]. Squared weights $\geq 0.05$ were retained as 'significant', and the greater a variable's weight, the more it is considered as a driver of the component [63]. Prior to running the PLSR models, sand, silt, clay, and XANES data were center log ratio transformed (clr; R package compositions). This transformation is necessary to convert compositional data (e.g., proportions and percentages) into an open form and analyzed in Euclidean space [64]. Survey 2 sites that had no chemical data except pH were not included in the analysis (FR_Rou, PT_Mit-mid, and PT_Mit-amb).

Principal component analysis (PCA; R packages FactoMineR and factoextra) was conducted with site-averaged, clr-transformed, predicted microbial pathway data, and $F_{20}, F_{40}$, and $Q_{10}$ data. The embedded BugBase statistical tests were also used to evaluate pairwise correlations between microbial pathway predictions and $F_{20}, F_{40}$, and $Q_{10}$ (Spearman's rank correlation).

Finally, raw $S$ XANES spectra (before composition estimation against reference spectra) were analyzed by dividing the $2470 \mathrm{eV}$ to $2486 \mathrm{eV}$ spectral region into 30 bins to assess correlations (pairwise Pearson's product moment) between the site-averaged soil chemical, physical, and microbial data and XANES absorption within each $0.5 \mathrm{eV}$ bin.

\section{Results}

\subsection{Patterns in OCS Production with Biome and Land Use}

OCS production was widespread across a collection of diverse soils. The surveys included soils with diverse biome, land use, and physicochemical characteristics (Table 3). Net emissions of OCS (positive flux) were observed in air-dried soils from approximately $90 \%$ of sites (51 of 58) from the two soil surveys in gas exchange rates measured in the dark at approximately $20{ }^{\circ} \mathrm{C}\left(20.5^{\circ} \mathrm{C}\right.$ for Survey $1 ; 17^{\circ} \mathrm{C}$ for Survey 2). Under these conditions, OCS fluxes ranged in Survey 1 from -0.7 to $39.5 \mathrm{pmol}$ (OCS) $\mathrm{kg} \mathrm{DW}^{-1} \mathrm{~min}^{-1}$ with a median of $2.3 \mathrm{pmol}(\mathrm{OCS}) \mathrm{kg} \mathrm{DW}^{-1} \mathrm{~min}^{-1}$ and in Survey 2 site-averaged OCS fluxes ranged from -12.2 to $18.0 \mathrm{pmol}(\mathrm{OCS}) \mathrm{kg} \mathrm{DW}^{-1} \mathrm{~min}^{-1}$ with a median of 0.9 pmol(OCS) $\mathrm{kg} \mathrm{DW}^{-1} \mathrm{~min}^{-1}$. The maximum emissions were observed in Boreal peatland samples for both surveys (MN-SP, SE-Abi). A minority of soils in both surveys exhibited net OCS uptake, although only one site with replicates was significantly different from zero (FR-Lou). A similar range of OCS fluxes was observed in both surveys (Figure 1) when considered under the same conditions $\left(17^{\circ} \mathrm{C}\right.$ in the dark; Section 2.2.2). The remainder of the results are derived from independent statistical analyses of Surveys 1 and 2. This prevents differences in methods (Table 2) from affecting data interpretation and also allows us to determine whether results are consistent across what are essentially two separate studies. 
Table 3. Survey 1 and 2 site information and selected physicochemical properties sorted by biome and land use.

\begin{tabular}{|c|c|c|c|c|c|c|c|c|c|c|c|}
\hline \multicolumn{12}{|c|}{ Survey 1} \\
\hline Soil ID & Latitude & Longitude & Biome & Land Use & $\mathrm{pH}$ & $\mathrm{C} / \mathrm{N}$ & Clay (\%) & Silt (\%) & Sand $(\%)$ & MAT $\left({ }^{\circ} \mathrm{C}\right)$ & MAP (mm \\
\hline UT-CR & 38.68 & -109.42 & Arid & Desert & 8.8 & 88 & 14 & 34 & 52 & 9.7 & 295 \\
\hline UT-MO & 38.87 & -109.81 & Arid & Desert & 9.4 & 172 & 36 & 58 & 6 & 10.9 & 225 \\
\hline CA-JRB & 37.4 & -122.23 & Mediterranean & Grassland & 7.5 & 12 & 11 & 37 & 52 & 14.6 & 618 \\
\hline CA-JRC & 37.41 & -122.23 & Mediterranean & Grassland & 7.3 & 11 & 11 & 39 & 50 & 14.6 & 618 \\
\hline CA-JRSN & 37.41 & -122.23 & Mediterranean & Grassland & 6.5 & 11 & 17 & 48 & 35 & 14.6 & 618 \\
\hline CA-JRSR & 37.41 & -122.23 & Mediterranean & Grassland & 7.4 & 12 & 10 & 43 & 47 & 14.6 & 618 \\
\hline CA-SR1 & 34.09 & -118.66 & Mediterranean & Evergreen Forest & 7.3 & 21 & 13 & 36 & 51 & 14.8 & 450 \\
\hline CA-SR2 & 34.09 & -118.66 & Mediterranean & Evergreen Forest & 7.6 & 17 & 8 & 33 & 59 & 14.8 & 450 \\
\hline CA-CC & 37.43 & -122.18 & Mediterranean & Cropland & 8.2 & 12 & 13 & 30 & 57 & 14.6 & 618 \\
\hline CA-BB & 37.19 & -122.22 & Temperate & Evergreen Forest & 6.4 & 25 & 10 & 36 & 54 & 14.6 & 618 \\
\hline OR-AC & 42.18 & -122.8 & Temperate & Evergreen Forest & 6.5 & 32 & 6 & 25 & 69 & 10.5 & 676 \\
\hline WA-WR & 45.82 & -121.95 & Temperate & Evergreen Forest & 5.3 & 33 & 1 & 4 & 95 & 8.4 & 1850 \\
\hline MA-HF & 42.54 & -72.17 & Temperate & Deciduous Forest & 4.3 & 21 & 4 & 26 & 70 & 8.8 & 1167 \\
\hline WI-WC & 45.81 & -90.08 & Temperate & Deciduous Forest & 5.8 & 15 & 3 & 15 & 82 & 4.7 & 812 \\
\hline IL-BV & 40.01 & -88.29 & Temperate & Cropland & 5.8 & 11 & 7 & 37 & 56 & 11.4 & 1013 \\
\hline OK-GP & 36.61 & -97.49 & Temperate & Cropland & 4.8 & 10 & 13 & 62 & 25 & 16.0 & 972 \\
\hline HI-KP & 20.15 & -155.83 & Tropical & Grassland & 6.6 & 10 & 7 & 26 & 67 & 20.3 & 2680 \\
\hline CM-DF & 11.51 & 105.01 & Tropical & Cropland & 5.5 & 9 & 28 & 62 & 10 & 28.2 & 1453 \\
\hline CM-WF & 11.51 & 105.01 & Tropical & Cropland & 4.6 & 10 & 25 & 59 & 16 & 28.2 & 1453 \\
\hline MN-SP & 47.51 & -93.45 & Boreal & Peatland & 4 & 33 & n.d. & n.d. & n.d. & 4.1 & 725 \\
\hline \multicolumn{12}{|c|}{ Survey 2} \\
\hline Soil ID & Latitude & Longitude & Biome & Land Use & $\mathrm{pH}$ & $\mathrm{C} / \mathrm{N}$ & Clay (\%) & Silt (\%) & Sand (\%) & MAT $\left({ }^{\circ} \mathrm{C}\right)$ & MAP (mm \\
\hline SP-Amo & 36.83 & -2.25 & Arid & Grassland & 8.6 & 9 & 15 & 35 & 50 & 18.1 & 291 \\
\hline SP-Bal & 39.94 & -2.03 & Arid & Grassland & 8.4 & 19 & 18 & 28 & 54 & 13.8 & 427 \\
\hline IS-Yat & 31.35 & 35.05 & Arid & Evergreen Forest & 8.1 & 30 & 29 & 49 & 22 & 21.0 & 217 \\
\hline IS-Reh & 31.91 & 34.81 & Mediterranean & Orchard & 7.8 & 18 & 15 & 7 & 78 & 20.3 & 485 \\
\hline SP-Ube_NOVeg & 37.92 & -3.23 & Mediterranean & Orchard & 8.4 & 42 & 55 & 40 & 5 & 15.7 & 422 \\
\hline SP-Ube_Veg & 37.91 & -3.23 & Mediterranean & Orchard & 8.6 & 13 & 23 & 35 & 42 & 15.7 & 422 \\
\hline FR-Pue & 43.74 & 3.6 & Mediterranean & Evergreen Forest & 6.9 & 18 & 42 & 32 & 26 & 13.8 & 755 \\
\hline PT-Cor & 39.14 & -8.33 & Mediterranean & Evergreen Forest & 5.7 & 18 & 4 & 16 & 80 & 16.7 & 811 \\
\hline PT-Mit-amb & 38.54 & -8 & Mediterranean & Evergreen Forest & 5.5 & n.d. & n.d. & n.d. & n.d. & 16.7 & 811 \\
\hline PT-Mit-b9 & 38.54 & -8 & Mediterranean & Evergreen Forest & 5.9 & 18 & 4 & 9 & 87 & 16.7 & 811 \\
\hline PT-Mit-mid & 38.54 & -8 & Mediterranean & Evergreen Forest & 6 & n.d. & n.d. & n.d. & n.d. & 16.7 & 811 \\
\hline SP-Cha & 40.65 & 0.21 & Mediterranean & Evergreen Forest & 5.5 & 19 & 13 & 20 & 67 & 15.3 & 490 \\
\hline
\end{tabular}


Table 3. Cont

\begin{tabular}{|c|c|c|c|c|c|c|c|c|c|c|c|}
\hline \multicolumn{12}{|c|}{ Survey 2} \\
\hline Soil ID & Latitude & Longitude & Biome & Land Use & $\mathrm{pH}$ & $\mathrm{C} / \mathrm{N}$ & Clay (\%) & Silt (\%) & Sand $(\%)$ & MAT $\left({ }^{\circ} \mathrm{C}\right)$ & MAP (mm \\
\hline SP-Peg & 40.38 & 4.19 & Mediterranean & Evergreen Forest & 6.2 & 11 & 3 & 9 & 88 & 16.7 & 603 \\
\hline $\mathrm{CH}-\mathrm{Ch}$ a & 47.21 & 8.41 & Temperate & Grassland & 6.3 & 27 & 28 & 44 & 28 & 9.5 & 1136 \\
\hline CH-Fru & 47.12 & 8.54 & Temperate & Grassland & 4.9 & 10 & 42 & 47 & 11 & 9.2 & 1282 \\
\hline FR-Laq1 & 45.64 & 2.74 & Temperate & Grassland & 4.6 & 11 & 18 & 59 & 23 & 8.2 & 985 \\
\hline FR-Laq2 & 45.64 & 2.74 & Temperate & Grassland & 5.7 & 11 & 21 & 57 & 22 & 8.2 & 985 \\
\hline $\mathrm{CH}-\mathrm{Dav}$ & 46.81 & 9.86 & Temperate & Evergreen Forest & 4.3 & 25 & 22 & 25 & 53 & 2.6 & 2135 \\
\hline FR-Gra & 44.76 & 0.6 & Temperate & Evergreen Forest & 4.6 & 27 & 4 & 5 & 91 & 13.2 & 794 \\
\hline FR-LeB & 44.72 & 0.77 & Temperate & Evergreen Forest & 4.8 & 25 & 4 & 3 & 93 & 13.2 & 794 \\
\hline CH-Lag & 47.12 & 8.54 & Temperate & Deciduous Forest & 6.3 & 13 & 42 & 43 & 15 & 9.2 & 1282 \\
\hline DE-Hai & 51.08 & 10.45 & Temperate & Deciduous Forest & 6 & 13 & 48 & 49 & 4 & 8.6 & 672 \\
\hline DE-Lei & 51.33 & 10.37 & Temperate & Deciduous Forest & 5.2 & 14 & 19 & 77 & 4 & 8.6 & 672 \\
\hline DK-Sor & 55.49 & 11.64 & Temperate & Deciduous Forest & 4.2 & 19 & 15 & 23 & 62 & 9.0 & 584 \\
\hline FR_Rou & 45.01 & 0.97 & Temperate & Deciduous Forest & 6.5 & n.d. & n.d. & n.d. & n.d. & 12.7 & 830 \\
\hline FR-Hes & 48.67 & 7.07 & Temperate & Deciduous Forest & 5.4 & 14 & 24 & 61 & 15 & 10.3 & 743 \\
\hline FR-Lou & 43.08 & -0.04 & Temperate & Deciduous Forest & 7.9 & 23 & 14 & 38 & 48 & 12.8 & 845 \\
\hline $\mathrm{CH}-\mathrm{Oe} 2$ & 47.29 & 7.73 & Temperate & Cropland & 7.3 & 10 & 42 & 47 & 11 & 9.1 & 1220 \\
\hline FR_TlsC6 & 43.54 & 1.51 & Temperate & Cropland & 8.6 & 22 & 18 & 35 & 47 & 13.9 & 660 \\
\hline FR TlsLA3 & 43.53 & 1.5 & Temperate & Cropland & 8.5 & 15 & 28 & 45 & 27 & 13.9 & 660 \\
\hline FR-AucB4 & 43.62 & 0.57 & Temperate & Cropland & 8.4 & 30 & 33 & 49 & 18 & 13.9 & 712 \\
\hline FR-AucLH8 & 43.64 & 0.6 & Temperate & Cropland & 7.8 & 8 & 47 & 35 & 18 & 13.9 & 712 \\
\hline FR-TlsCL & 43.53 & 1.51 & Temperate & Cropland & 5.7 & 8 & 33 & 42 & 25 & 13.9 & 660 \\
\hline SE-Abi & 68.36 & 19.05 & Boreal & Peatland & 4.4 & 39 & n.d. & n.d. & n.d. & -3.1 & 690 \\
\hline SE-Hyl & 56.1 & 13.42 & Boreal & Peatland & 3.8 & 26 & 14 & 35 & 51 & 7.7 & 849 \\
\hline FI-Hyy & 61.85 & 24.3 & Boreal & Evergreen Forest & 4.6 & 36 & 14 & 32 & 54 & 3.9 & 579 \\
\hline FI-Var & 67.76 & 29.62 & Boreal & Evergreen Forest & 5.3 & 31 & 4 & 17 & 79 & -0.6 & 578 \\
\hline SE-Nor & 60.09 & 17.47 & Boreal & Evergreen Forest & 4.4 & 31 & 13 & 26 & 61 & 5.9 & 576 \\
\hline SE-Ros_Cont & 64.17 & 19.75 & Boreal & Evergreen Forest & 5.2 & 41 & 4 & 15 & 81 & 2.0 & 635 \\
\hline SE-Ros_Fert & 64.17 & 19.75 & Boreal & Evergreen Forest & 4.5 & 27 & 4 & 30 & 66 & 2.0 & 635 \\
\hline SE-Sva & 64.17 & 19.78 & Boreal & Evergreen Forest & 4.7 & 47 & 9 & 28 & 63 & 2.0 & 635 \\
\hline
\end{tabular}

n.d. not determined. 


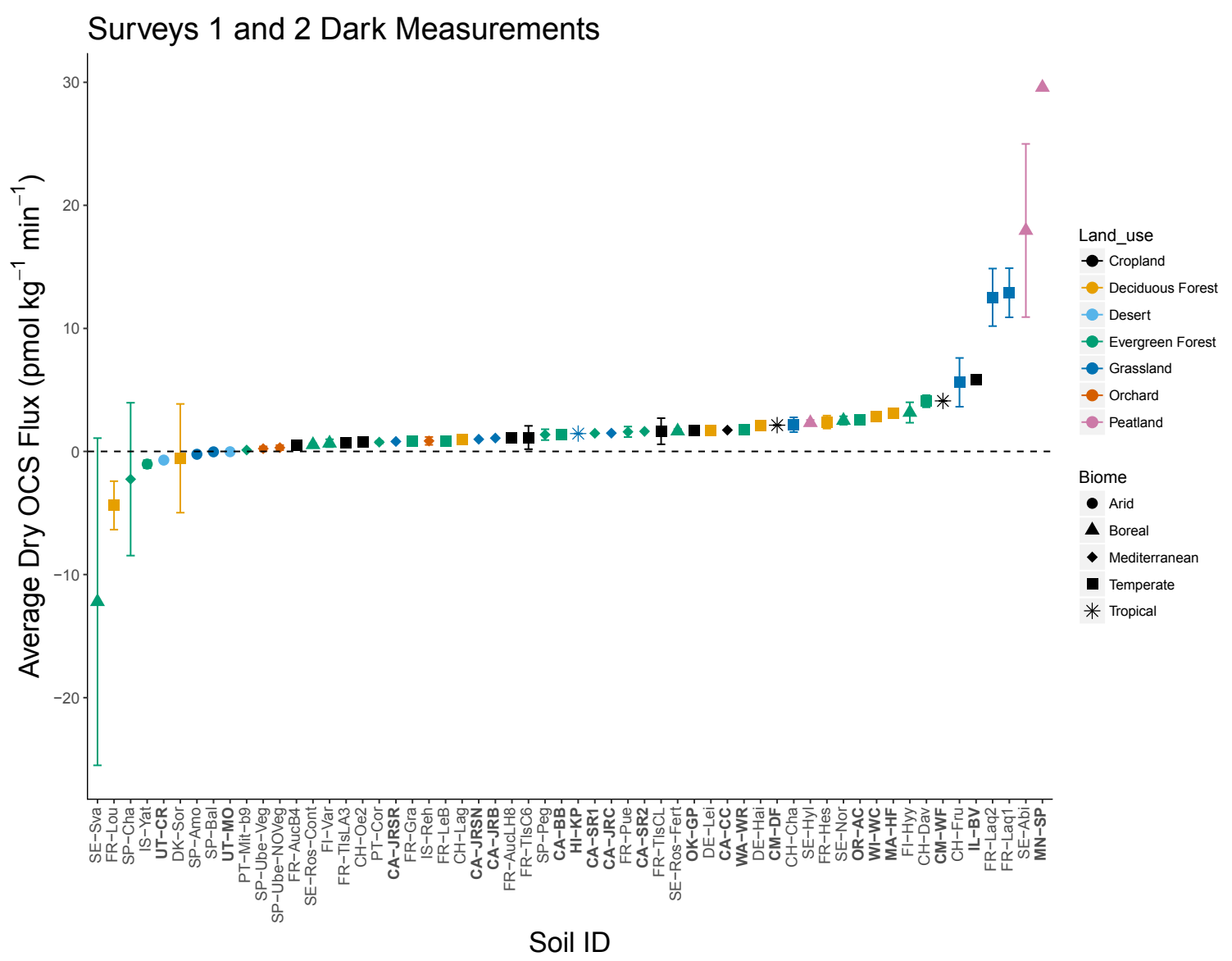

Figure 1. Net OCS soil fluxes from two independent soil surveys measured at approximately $17^{\circ} \mathrm{C}$ in the dark in Survey 1 (bold text) and Survey 2 (normal text). Survey 1 fluxes at $17^{\circ} \mathrm{C}$ were estimated from measured fluxes at $20.5^{\circ} \mathrm{C}$ using the temperature sensitivity for each soil. Site biome is indicated by symbol type and land use by color. Error bars represent standard deviation of three soil replicates measured in Survey 2. Positive OCS fluxes indicate emissions of OCS from soils, while negative fluxes indicate net OCS uptake.

Biome was a significant predictor variable for OCS fluxes in both surveys, and the patterns with biome were similar for the two surveys (Table 4) increasing from net OCS uptake (negative values) in arid soils to net OCS emission (positive) in all other soils in the following order: arid $<$ Mediterranean $<$ boreal $<$ temperate $<$ tropical soils. Differences were most significant at $40{ }^{\circ} \mathrm{C}$ (Table 4 ), where arid and Mediterranean soils were both significantly lower than temperate and tropical soils, although differences in production rates between the latter were not significant. Land use was a significant predictor variable for Survey 2, but not for Survey 1 in any model $\left(p=0.31 F_{20} ; p=0.19 F_{40}\right)$. Land use was significant in distinguishing grassland from deciduous and evergreen forests and cropland, but the orchards did not have significantly different $F_{20}$ from other land use types (Table 2). 
Table 4. The effect of biome and land use on Survey 1 OCS fluxes at $20{ }^{\circ} \mathrm{C}$ and $40{ }^{\circ} \mathrm{C}\left(F_{20}\right.$ and $F_{40}$, respectively) and temperature sensitivity $\left(Q_{10}\right)$ and on Survey $2 F_{20}$. The same within a column letter means no statistical difference $(\alpha=0.05)$ between factor levels; factor levels with two letters means no statistical difference between factor levels with either letter. Survey $1 F_{20}$ and $F_{40}$ were log transformed for analysis and back-transformed for presentation.

\begin{tabular}{|c|c|c|c|c|}
\hline \multirow[t]{2}{*}{ Effect } & \multicolumn{3}{|c|}{ Survey 1} & \multirow{2}{*}{$\begin{array}{c}\text { Survey } 2 \\
F_{20}\end{array}$} \\
\hline & $F_{20}$ & $F_{40}$ & $Q_{10}$ & \\
\hline & \multicolumn{4}{|c|}{ ANOVA $p$-value } \\
\hline Biome & $<0.001$ & $<0.001$ & $<0.001$ & $<0.001$ \\
\hline Land use & 2 & 2 & 2 & $<0.001$ \\
\hline Lsmeans & \multicolumn{2}{|c|}{$\left(\mathrm{pmol} \mathrm{OCS} \mathrm{kg}{ }^{-1} \mathrm{~min}^{-1}\right)$} & - & $\left(\mathrm{pmol}\right.$ OCS $\left.\mathrm{kg}^{-1} \min ^{-1}\right)$ \\
\hline Arid & $-0.46 \mathrm{~B}$ & $0.44 \mathrm{C}$ & $1.65 \mathrm{C}$ & $-2.93 \mathrm{~B}$ \\
\hline Mediterranean & $1.73 \mathrm{~A}$ & $8.74 \mathrm{~B}$ & $2.66 \mathrm{~B}$ & $0.38 \mathrm{AB}$ \\
\hline Boreal & 3 & 3 & 3 & $0.59 \mathrm{AB}$ \\
\hline Temperate & $3.44 \mathrm{~A}$ & $21.48 \mathrm{~A}$ & $2.83 \mathrm{AB}$ & $3.72 \mathrm{~A}$ \\
\hline Tropical & $3.37 \mathrm{~A}$ & $23.90 \mathrm{~A}$ & $3.18 \mathrm{~A}$ & 1 \\
\hline Deciduous Forest & 2 & 2 & 2 & $-2.02 \mathrm{~B}$ \\
\hline Cropland & 2 & 2 & 2 & $-1.62 \mathrm{~B}$ \\
\hline Evergreen Forest & 2 & 2 & 2 & $0.33 \mathrm{~B}$ \\
\hline Orchard & 1 & 1 & 1 & $0.84 \mathrm{AB}$ \\
\hline Grassland & 2 & 2 & 2 & $4.64 \mathrm{~A}$ \\
\hline Peatland & 3 & 3 & 3 & 1 \\
\hline Desert & 2 & 2 & 2 & 1 \\
\hline
\end{tabular}

\subsection{Temperature Response of OCS Production}

Soil OCS emissions increased with temperature $\left(15\right.$ to $\left.40{ }^{\circ} \mathrm{C}\right)$ for all Survey 1 soils. Temperature sensitivity expressed as $Q_{10}$ varied between 1.54 and 3.32 and was on average $2.70 \pm 0.21$ (Figure 2) ( $\pm 95 \%$ confidence intervals). Desert soils were net sinks of OCS at $20^{\circ} \mathrm{C}$ and transitioned to sources of OCS at higher temperatures. $Q_{10}$ varied with biome (arid $<$ Mediterranean $<$ temperate $<$ tropical) in the same order as OCS fluxes (see Section 3.1), and biome was a significant predictor variable distinguishing arid from Mediterranean and tropical soils, though temperate soils were not distinguishable from either Mediterranean or tropical soils (Table 4). Land use was not a significant predictor variable for temperature sensitivity $\left(p=0.81 Q_{10}\right)$.

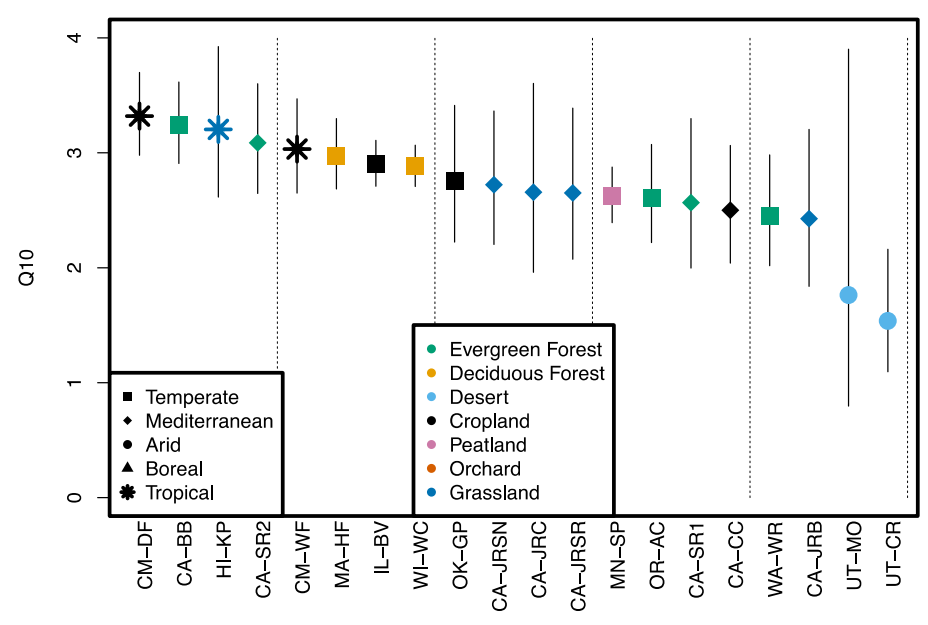

Figure 2. OCS production temperature sensitivity $\left(Q_{10}\right)$ for Survey 1 soils observed over temperature ramp between $15^{\circ} \mathrm{C}$ and $40{ }^{\circ} \mathrm{C}$ in the dark. Site biome is indicated by symbol type and land use by color. Error bars indicate upper and lower $95 \%$ confidence intervals on exponential fit. 


\subsection{Light Response of OCS Production}

OCS emissions increased with light in most Survey 2 soils (33 out of 38). Light and dark OCS emissions were correlated (Pearson correlation; $r=0.89 p<0.001$ ), and OCS emissions in the light were $2.34 \pm 0.06$ times higher than in the dark (York fit linear slope [65]). However, the increase in temperature between light and dark treatments-a $6{ }^{\circ} \mathrm{C}$ change (from 17 to $23^{\circ} \mathrm{C}$ )—can already explain a factor of 2 increase in OCS production for a $Q_{10}$ of 3 (i.e., $3^{0.6} \sim 2$ ). A linear model with conditioning (light vs. dark) as a fixed effect determined that conditioning was not a significant predictor $(P=0.12)$, and a linear model that used light sensitivity (i.e., light vs. dark conditioning) as the response variable was also run; neither biome nor land use were significant predictors ( $\mathrm{P}=0.48$ and $\mathrm{P}=0.9$ respectively).

\subsection{Soil Sulfur Speciation}

The relative and absolute abundance of soil $\mathrm{S}$ species varied across the soils in Survey 1. Soil $\mathrm{S}$ ranged from 0.02 to $0.70 \% \mathrm{gS} \mathrm{g} \mathrm{DW}{ }^{-1}$ with a median of $0.04 \% \mathrm{gS} \mathrm{g} \mathrm{DW}^{-1}$ (Table 5). Soil S levels were exceptionally high in peat, which contained significant fractions of dead plant biomass (MN-SP). Most sulfur was present in the form of organic compounds in our soils. Inorganic sulfate $\left(\mathrm{SO}_{4}\right)$ was exceptionally high in tropical CM-WF soils $\left(43.2 \% \mathrm{~g}\left(\mathrm{SO}_{4}\right) \mathrm{gS}^{-1}\right)$ and ranged from 0.2 and $12.4 \% \mathrm{~g}\left(\mathrm{SO}_{4}\right)$ $\mathrm{gS}^{-1}$ in the remaining soil samples, with a median of $0.6 \%$. Adsorbed sulfate was present in six out of the eight soils with the highest soil sulfate levels, but the majority of soils (17 out of 20 ) had greater amounts of sulfate in water soluble than in the adsorbed phase.

Table 5. Selected soil S properties and stoichiometric ratios sorted by biome and land use (Survey 1).

\begin{tabular}{ccccccc}
\hline Site & S (\%) & C/N & C/S & N/S & P/S & SO $_{\mathbf{4}}$ (IC) (mg/kgS) \\
\hline UT-CR & 0.03 & 88 & 81 & 1 & 2 & 0.9 \\
UT-MO & 0.05 & 172 & 37 & 0 & 2 & 2.7 \\
CA-JRB & 0.02 & 12 & 67 & 6 & 1 & 0.3 \\
CA-JRC & 0.04 & 11 & 61 & 6 & 2 & 0.4 \\
CA-JRSN & 0.02 & 11 & 64 & 6 & 1 & 0.3 \\
CA-JRSR & 0.02 & 12 & 108 & 9 & 1 & 0.3 \\
CA-BB & 0.04 & 25 & 125 & 5 & 4 & 0.2 \\
CA-SR1 & 0.04 & 21 & 41 & 2 & 3 & 0.2 \\
CA-SR2 & 0.06 & 17 & 63 & 4 & 2 & 0.4 \\
CA-CC & 0.04 & 12 & 34 & 3 & 2 & 1.8 \\
OR-AC & 0.06 & 32 & 105 & 3 & 1 & 0.2 \\
WA-WR & 0.03 & 33 & 141 & 4 & 3 & 4.2 \\
MA-HF & 0.12 & 21 & 70 & 3 & 1 & 3.5 \\
WI-WC & 0.09 & 15 & 53 & 4 & 1 & 0.6 \\
IL-BV & 0.03 & 11 & 73 & 7 & 1 & 0.5 \\
OK-GP & 0.03 & 10 & 37 & 4 & 0 & 0.9 \\
HI-KP & 0.10 & 10 & 50 & 5 & 7 & 1.2 \\
CM-DF & 0.05 & 9 & 22 & 3 & 1 & 12.4 \\
CM-WF & 0.10 & 10 & 23 & 2 & 0 & 43.2 \\
MN-SP & 0.66 & 33 & 64 & 2 & 1 & S 0.2 \\
\hline
\end{tabular}

${ }^{\mathrm{S}}$ Total IC-derived sulfate listed, except where noted as soluble sulfate only.

We used bulk S K-edge XANES spectroscopy to determine the relative abundance of inorganic sulfate $\left(\mathrm{SO}_{4}\right)$ and organic compounds including organic disulfides (R-S-S-R'), organic sulfides (R-S- $\left.\mathrm{R}^{\prime}\right)$, thiols (R-SH), sulfoxides (R-SO-R'), sulfonates (R-O-SO $\left.\mathrm{S}_{2}\right)$, and organic sulfate $\left(\mathrm{R}-\mathrm{O}-\mathrm{SO}_{3}\right)$ (Figure 3a). Soil samples differed markedly in their sulfur speciation profiles, the highest proportion of organic sulfur on average was organic sulfate (31\%), followed by organic sulfonate $(19 \%)$, disulfide $(18 \%)$, sulfide $(15 \%)$, sulfoxide $(7 \%)$, and thiol $(1 \%)$. Inorganic sulfate concentrations determined by XANES and IC did not quantitatively agree (Figure 3a). This can primarily be attributed to uncertainty in XANES data, which are semi-quantitative for species classifications and may not reliably distinguish 
between sulfur species with very similar structure (e.g., organic and inorganic sulfate) in complex matrices, such as soil. We evaluated ratios of highly reduced organic $S$ (RS) and intermediately oxidized organic S (RI) to highly oxidized organic S (RS = (R-S-S-R' + R-S-R' + R-SH) $/ \mathrm{R}-\mathrm{O}_{-}-\mathrm{SO}_{3} ; \mathrm{RI}=\left(\mathrm{R}-\mathrm{SO}-\mathrm{R}^{\prime}+\right.$ $\mathrm{R}-\mathrm{O}-\mathrm{SO}_{2}$ ) $/ \mathrm{R}-\mathrm{O}-\mathrm{SO}_{3}$ ) (Figure 3b). RS and RI were largest in peatland (MN-SP) and smallest in an arid (UT-CR) site, representing extremes in sulfur redox speciation (reduced and oxidized, respectively). $\mathrm{S}$ redox ratios were close to unity in most soils (1.2 for RS and 0.9 for RI in the median). Higher $\mathrm{S}$ redox ratios were found in some (e.g., WA-WR, MA-HF), but not all forests. Furthermore, $\mathrm{S}$ was more oxidized in the well-drained location (CM-DF) of the tropical agricultural site and more reduced in the water-logged location (CM-WF).

\section{(a) XANES: S Speciation}

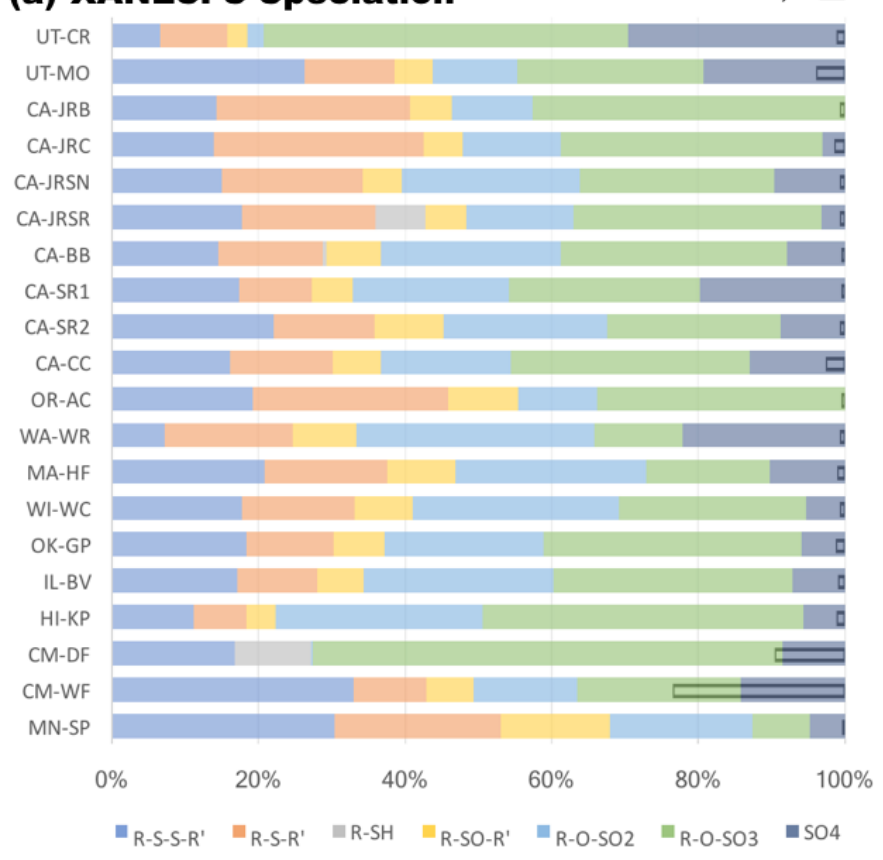

\section{(b) S Ratios}

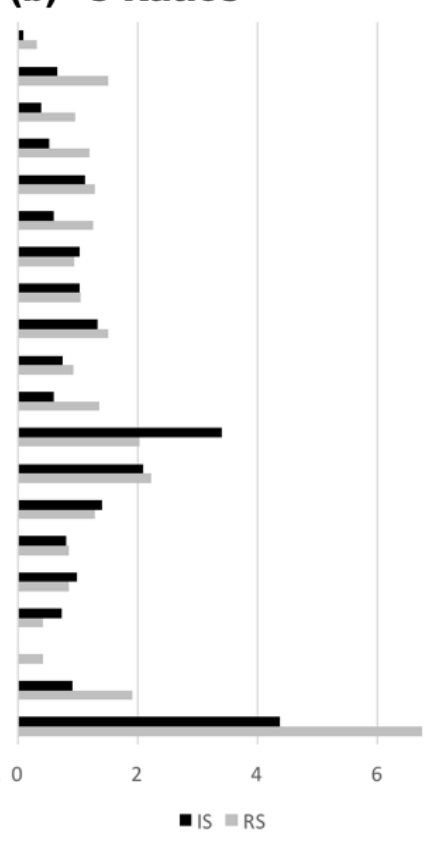

Figure 3. Soil sulfur speciation (Survey 1). For each site, (a) relative proportion of sulfur species (\% total S) as measured by XANES (solid bars) and compared with total sulfate measured by IC (right-justified outline bars); and (b) S species ratios including (RS) highly reduced to highly oxidized (grey bars) and (IS) intermediate oxidized to highly oxidized (black bars). Sites ordered as in Table 5.

\subsection{Sulfur Cycling in Soil Microbial Communities}

Microbial function predicted from community composition of soils prior to drying may yield information regarding $S$ compounds relevant to OCS production. We estimated the relative abundance of microbial S cycling pathways (see Section 2.3.1), including dissimilatory (e.g., sulfate reduction), assimilatory (e.g., cysteine biosynthesis), degradation (e.g., methionine degradation), and transport (e.g., sulfate transport) pathways. OCS production was correlated with the predicted prevalence of biosynthesis of S-containing amino acids such as cysteine (R-SH) and methionine (R-S-R'). PCA analysis of predicted microbial pathways (Figure 4 ) associated $F_{20}, F_{40}$, and $Q_{10}$ with the biosynthetic pathways for cysteine, methionine, thiamine (vitamin B1 synthesized from cysteine, S-containing pentane ring), and ethylene (by-product in methionine salvage pathway) along Dimension 2, which also separated sites by biome. Along Dimension 2, transport of methionine, glutathione (R-SH; essential S carrier in some organisms), and cystine (R-S-S-R') and methionine degradation (to homocysteine, R-SH) also increased with OCS production, while methionine salvage (as opposed to degradation) decreased. OCS production terms were nearly orthogonal to sulfate cycling pathways, which were aligned with Dimension 1. This axis separated soils with high proportions of bacteria and sulfate reduction from those with relatively more eukaryotes and archaea, organic sulfur degradation, and sulfate transport. 
Cysteine biosynthesis by the two different pathways were orthogonal in the PCA, with alignment of bacterial cysteine biosynthesis from serine along Dimension 2 in contrast to fungal cysteine biosynthesis from homocysteine along Dimension 1. Soils from the Mediterranean biome were more similar in predicted S cycling than those collected from temperate biomes, which spanned the variance of Dimension 1.

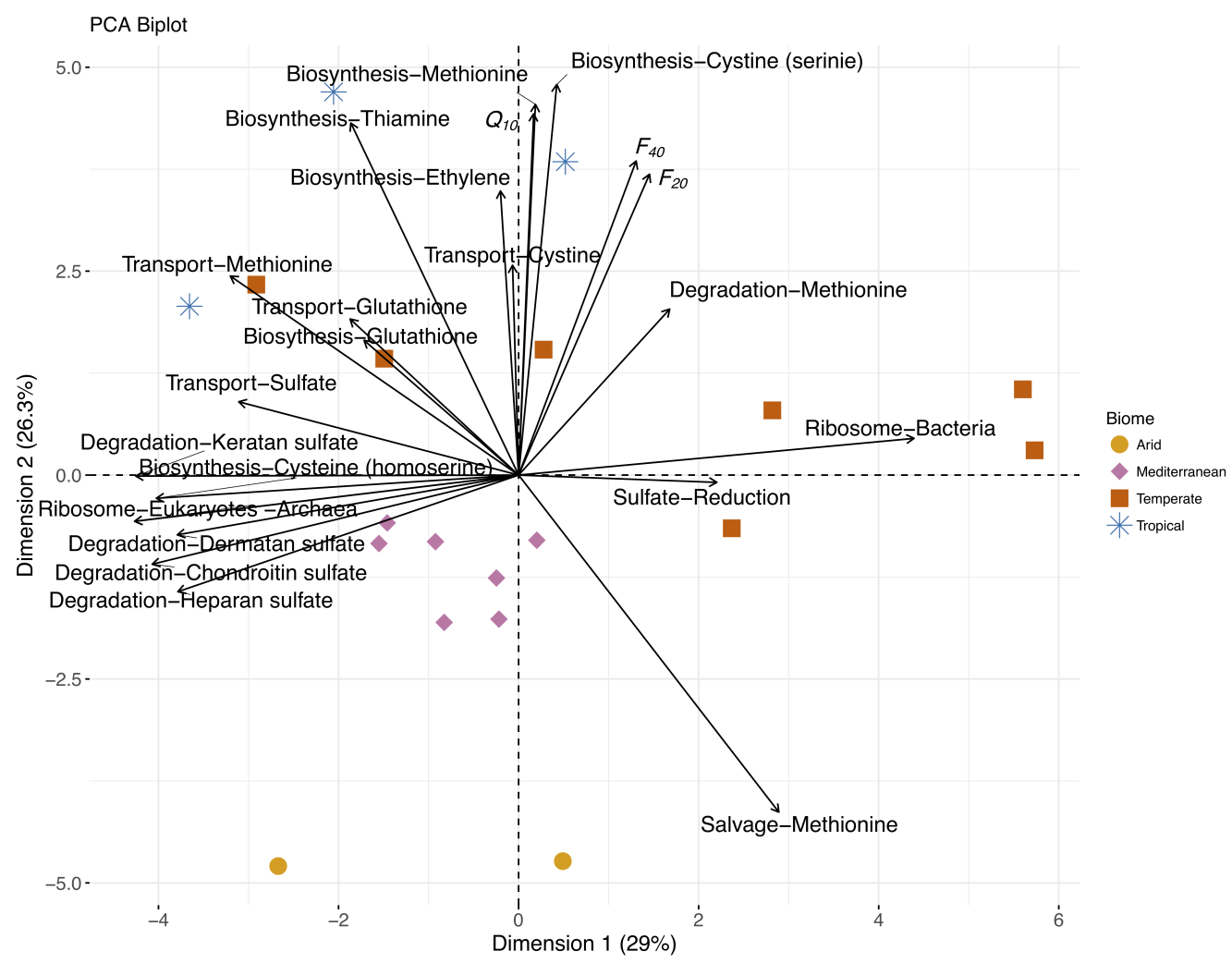

Figure 4. Patterns of relatedness of S-cycling pathways and ribosomal phenotypes for each sample site PCA of predicted microbial sulfur pathways for each site (points; color indicates biome, symbol indicates land use). Arrows denote the projection of pathways (similar pathways marked by same color) and OCS fluxes and temperature sensitivity onto Dimension 1 (29\%) and Dimension 2 (26.3\%).

In a complementary analysis, we recovered genes encoding for thiocyanate hydrolase $(\operatorname{scn} C)$ from soil metatranscriptomes from a subset of moist soil replicates from Survey 1 (Section 2.3.3). The results, including the frequency of assembled $\operatorname{scn} C$ genes per million genes in the transcriptomes, are presented in Appendix A. We did not observe a correlation between thiocyanate hydrolase $(\operatorname{scn} C)$ gene expression in moist soils (Table A1) and OCS production measured in soils following a median of 45 days of air drying.

\subsection{Multivariate Analysis of Soil Factors Contributing to OCS Production}

\subsubsection{PLSR Models of Factors Driving $F$ and $Q_{10}$}

The cumulative amount of variance explained in the PLSR models of Survey 1 data was 0.58 for $F_{20}, 0.63$ for $F_{40}$, and 0.88 for $Q_{10}$. In all PLSR models (Table 6), the second component accounted for a much smaller amount of variance than the first component. In $F$ models, significant weights $(\mathrm{w})$ were relatively consistent between the first component of each model. The main driver (i.e., greatest absolute weight) of $F$ in both Survey 1 models was $\mathrm{pH}$, which had a negative association with the first component of each model. Positively associated drivers included N, $\mathrm{SO}_{4}$, Microbial C, while other negatively associated drivers included $\mathrm{C} / \mathrm{N}, \mathrm{P}$, and R-S-R'. BD and $\mathrm{C}$ were drivers of the second 
component, and $\mathrm{S}$ was never a significant driver. Drivers shared between $F$ and $Q_{10}$ had the same sign and included $\mathrm{pH}, \mathrm{N}$, and $\mathrm{C} / \mathrm{N}$, but unlike $F, Q_{10}$ was negatively associated with $\mathrm{BD}$ (the main driver) and positively associated with R-SO- $\mathrm{R}^{\prime}$ in the first component, and to additional $\mathrm{S}$ species in the second component (Table 6). The cumulative amount of variance explained in the PLSR mode of Survey 2 was 0.34 , less than was explained for Survey 1 (Table 6). Drivers were shared between the two surveys (including the direction of association) for $\mathrm{pH}, \mathrm{N}$, and C/N. In Survey 2, C emerged as a negatively associated driver, and redox (not measured in Survey 1 ) was a positively associated driver with the second greatest $\mathrm{w}$ (second to $\mathrm{N}$ ).

Table 6. PLSR model summaries for Survey 1 . OCS flux at $20^{\circ} \mathrm{C}$ and $40^{\circ} \mathrm{C}$, and temperature sensitivity $\left(Q_{10}\right)$. Weights were retained as 'significant' for squared values $\geq 0.05$. The magnitude of the weight (w) of each predictor variable within each component (C1 and C2) show how much information is retained; predictors with the highest $\mathrm{w}$ can be interpreted as being drivers of the component. The +/ indicate the correlation relationship the predictor has with the response variable. Clr-transformed variables are labeled.

\begin{tabular}{|c|c|c|c|c|c|c|c|c|}
\hline & \multicolumn{6}{|c|}{ Survey 1} & \multirow{2}{*}{\multicolumn{2}{|c|}{$\frac{\text { Survey } 2}{F_{O C S, 20 C}}$}} \\
\hline & \multicolumn{2}{|c|}{$F_{O C S, 20 C}$} & \multicolumn{2}{|c|}{$F_{O C S, 40 C}$} & \multicolumn{2}{|c|}{$Q_{10}$} & & \\
\hline & $\mathrm{C} 1 \mathrm{R}^{2}$ & $\mathrm{C} 2 \mathrm{R}^{2}$ & $\mathrm{C} 1 \mathrm{R}^{2}$ & $\mathrm{C} 2 \mathrm{R}^{2}$ & $\mathrm{C} 1 \mathrm{R}^{2}$ & $C 2 R^{2}$ & $\mathrm{C} 1 \mathrm{R}^{2}$ & $\mathrm{C} 2 \mathrm{R}^{2}$ \\
\hline & 0.51 & 0.07 & 0.55 & 0.07 & 0.74 & 0.15 & 0.30 & 0.04 \\
\hline Predictors & $\mathrm{C} 1 \mathrm{w}$ & $\mathrm{C} 2 \mathrm{w}$ & $\mathrm{C} 1 \mathrm{w}$ & $\mathrm{C} 2 \mathrm{w}$ & $\mathrm{C} 1 \mathrm{w}$ & $\mathrm{C} 2 \mathrm{w}$ & $\mathrm{C} 1 \mathrm{w}$ & $\mathrm{C} 2 \mathrm{w}$ \\
\hline BD & 2 & 0.45 & 2 & 0.51 & -0.24 & 2 & 1 & 1 \\
\hline $\mathrm{pH}$ & -0.49 & 2 & -0.51 & 2 & -0.39 & 2 & -0.30 & -0.29 \\
\hline Clay (clr) & 2 & 2 & 2 & 2 & 2 & 0.26 & 2 & -0.68 \\
\hline Silt (clr) & 2 & 2 & 2 & 2 & 2 & 0.22 & 2 & 2 \\
\hline Sand (clr) & 2 & 2 & 2 & 2 & 2 & -0.25 & 2 & 0.45 \\
\hline GWC & 2 & 2 & 2 & 2 & 0.22 & 2 & 1 & 1 \\
\hline Microbial C & 0.22 & -0.29 & 0.22 & -0.29 & 2 & -0.27 & 1 & 1 \\
\hline Microbial N & 2 & -0.29 & 2 & -0.30 & 2 & -0.28 & 1 & 1 \\
\hline $\mathrm{C} / \mathrm{N}$ & -0.35 & 2 & -0.30 & 2 & -0.43 & 2 & -0.46 & 2 \\
\hline $\mathrm{C} / \mathrm{S}$ & 2 & 2 & 2 & 2 & 2 & -0.22 & 1 & 1 \\
\hline$C(\mathrm{clr})$ & 2 & -0.26 & 2 & 2 & 2 & -0.42 & -0.44 & 0.23 \\
\hline $\mathrm{N}$ (clr) & 0.34 & 2 & 0.30 & -0.23 & 0.40 & 2 & 0.44 & -0.23 \\
\hline $\mathrm{P}(\mathrm{clr})$ & -0.28 & 2 & -0.28 & 2 & 2 & 2 & 1 & 1 \\
\hline $\mathrm{K}(\mathrm{clr})$ & 2 & 0.35 & 2 & 0.30 & -0.23 & 0.21 & 1 & 1 \\
\hline $\mathrm{ISO}_{4}(\mathrm{mg} / \mathrm{kgS})$ & 0.28 & 0.23 & 0.37 & 0.28 & 2 & 2 & 1 & 1 \\
\hline R-S-S-R' (clr) & 2 & 0.22 & 2 & 2 & 2 & 0.26 & 1 & 1 \\
\hline R-S-R' (clr) & -0.24 & -0.40 & -0.27 & -0.38 & 2 & -0.30 & 1 & 1 \\
\hline R-SO-R' (clr) & 2 & 2 & 2 & 2 & 0.33 & 0.21 & 1 & 1 \\
\hline $\mathrm{R}-\mathrm{O}-\mathrm{SO}_{3}(\mathrm{clr})$ & -0.21 & 2 & 2 & 2 & 2 & 0.22 & 1 & 1 \\
\hline $\mathrm{X}_{\mathrm{SO}_{4}}(\mathrm{clr})$ & 2 & 2 & 2 & 0.24 & 2 & 2 & 1 & 1 \\
\hline Redox & 1 & 1 & 1 & 1 & 1 & 1 & 0.38 & 0.28 \\
\hline$F_{\mathrm{CO} 2}$ & 1 & 1 & 1 & 1 & 1 & 1 & 2 & 2 \\
\hline
\end{tabular}

${ }^{1}$ not applicable to data set; ${ }^{2}$ not significant; ${ }^{\mathrm{I} I C}$ - and ${ }^{\mathrm{X}}$ XANES-derived sulfate.

\subsubsection{Integrated Analysis of Microbial and Chemical Factors Driving OCS Production}

We evaluated correlations of soil properties with S XANES absorption spectra in each of 30 $(0.5 \mathrm{eV})$ bins to assess patterns in $\mathrm{S}$ compounds, soil properties, and microbial pathways. This analysis complements results derived from direct comparison to XANES reference spectra (e.g., PLSR analysis in Table 6), as the correlation approach allows patterns to emerge through indirect comparison. Clustering patterns with soil properties and microbial pathways highlighted potentially relevant processes. Four clusters, characterized by sulfur redox state, emerged from the correlation analysis: (1) highly oxidized S, (2) broad range intermediate $S$ redox states, (3) highly reduced $S$, and (4) intermediate $S$ redox states emphasizing a narrow range in potential. 
Reduced $\mathrm{S}$ regions of the XANES spectrum were associated with soil S, $\mathrm{SO}_{4}$ (measured by IC), and sulfate reduction pathways (Cluster 3). These low energy regions may also include pyrite (FeS) and elemental sulfur, although their presence was not indicated when tested as reference species for this study. In contrast, highly oxidized XANES regions for inorganic and organic sulfate were associated with sulfate transport and pathways for sulfate acquisition (e.g., organic sulfate degradation) (Cluster 1), which were generally anti-correlated with availability of reduced S compounds such as $\mathrm{S}$ amino acids (Cluster 4). Variables associated with microbial diversity and abundance were most associated with a broad range of intermediate $S$ (Cluster 2). Finally, a more narrow, intermediate range of $\mathrm{S}$ compounds were associated with biosynthetic pathways for cysteine (serine pathway; bacterial), methionine, ethylene, and thiamine, with $F$ and $Q_{10}$, and with $\mathrm{N} / \mathrm{C}$ and $\mathrm{pH}$ (Cluster 4). This narrow energy range ( 2479.75 to $2480.75 \mathrm{eV}$ ) is associated with sulfone reference compounds such as dibenzyl sulfonate [66].

\section{Discussion}

\subsection{Ubiquitous OCS Production in Soils}

OCS production is ubiquitous in dry soils, though may be masked at low temperatures in arid and alkaline soils by persistent OCS uptake. OCS production was widespread in our 58-site soil survey occurring in $84 \%$ of sites at temperatures between $17^{\circ} \mathrm{C}$ and $20.5^{\circ} \mathrm{C}$ in (Figure 1). Conversely, net OCS uptake was observed in nine dry soils. Three of these soils (SE-Sva, SP-Cha, DK-Sor) were also net $\mathrm{CO}_{2}$ emitters, suggesting that microbial activity persisted in those soils, including respiration and potentially CA activity. Soil moisture was not determined after air drying in Survey 2, but the $\mathrm{CO}_{2}$ fluxes may suggest that the soils were not sufficiently dried. In total, net $\mathrm{CO}_{2}$ emissions were observed

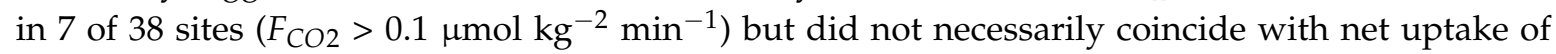
OCS. Therefore, while $F_{\mathrm{CO} 2}$ may be a proxy for microbial activity in some soils, or even influence OCS fluxes [9], it was not a predictor of trends in dry OCS fluxes, as confirmed by the PLSR analysis (Table 6). The six other soils that took up OCS in Survey 2 and the two in Survey 1 shared the following characteristics: arid or temperate biomes, alkaline ( $\mathrm{pH}$ between 7.9 and 9.4), and $F_{\mathrm{CO} 2}<0$. Alkaline and saline soils are known to exhibit net $\mathrm{CO}_{2}$ uptake as a result of abiotic $\mathrm{CO}_{2}$ dissolution, and in some cases leaching, of dissolved inorganic carbon [67], and rates of CA-catalyzed $\mathrm{CO}_{2}$ hydration increase at high $\mathrm{pH}$ [47]. While we know that uncatalyzed OCS hydrolysis rates increase dramatically at high $\mathrm{pH}$ [47] and found that $\mathrm{pH}$ was the dominant driver for OCS production (Table 6), the $\mathrm{pH}$-dependency of CA-catalyzed OCS uptake is not known. Survey 1 soils that took up OCS were very dry (e.g., 1.3\% and $2.2 \%$ GWC for UT-CR and UT-MO, respectively), making it unlikely that microbial CA were active $[10,13]$. It is currently difficult to infer mechanisms regarding OCS uptake in dry soils from our understanding of soil $\mathrm{CO}_{2}$ fluxes or soil CA activity. Even so, all Survey 1 soils produced OCS at high temperatures (Figure S1) suggesting that OCS production at low temperature was masked by OCS consumption. Correspondingly, we found that OCS production was a variable but ubiquitous process in soil.

\subsection{Mechanisms of OCS Production in Soils}

\subsubsection{OCS Production from Thermal and Photo Degradation}

Thermal degradation appears to be a key feature of soil OCS production, and variability in the degree of temperature sensitivity is related to soil properties. In recent work, the temperature sensitivity of OCS production determined from two-point temperature measurements in 27 moist soils (some identical samples to Survey 2) spanned a wide range of $Q_{10}$ values (from 0 to $>7$ ) with a mean and $S D$ of $4.36 \pm 4.45$ [10]. Other studies have reported $Q_{10}$ values between 1.7 and 3.3 [7,8,11,68]. In our soils (Survey 1), $Q_{10}$ ranged from 1.54 to 3.32 , and was on average $2.70 \pm 0.21$ ( $\pm 95 \%$ confidence intervals). Two of the same sites used in Survey 1 were previously shown to have $Q_{10}$ values of 2.66 in 
air-dried soils (2.92 in this study) for IL-BV [8] and $Q_{10}$ values of 2.16 in dry soil (2.75 in this study) for OK-GP [7], and differences may be related to temporal or spatial variability, or differences in the range of temperatures use to determine $Q_{10}$. Soils with high $\mathrm{N}$ and $\mathrm{RSOR}$ and low $\mathrm{pH}, \mathrm{C} / \mathrm{N}$, and $\mathrm{BD}$ had the highest $Q_{10}$ (Table 6), which is consistent with trends observed by PCA analysis (with $\mathrm{N}, \mathrm{pH}$, and $\mathrm{BD}$ ) [10]. We showed that $Q_{10}$ may be associated with $\mathrm{S}$ compounds such as sulfones (R-O-SO $\left.\mathrm{S}_{2}\right)$ and either disulfides (R-S-S-R'), elemental sulfur, or pyrite (Figure 5). Thus, thermal sensitivity is an important property of soils to constrain for predicting variability in OCS production across ecosystems.
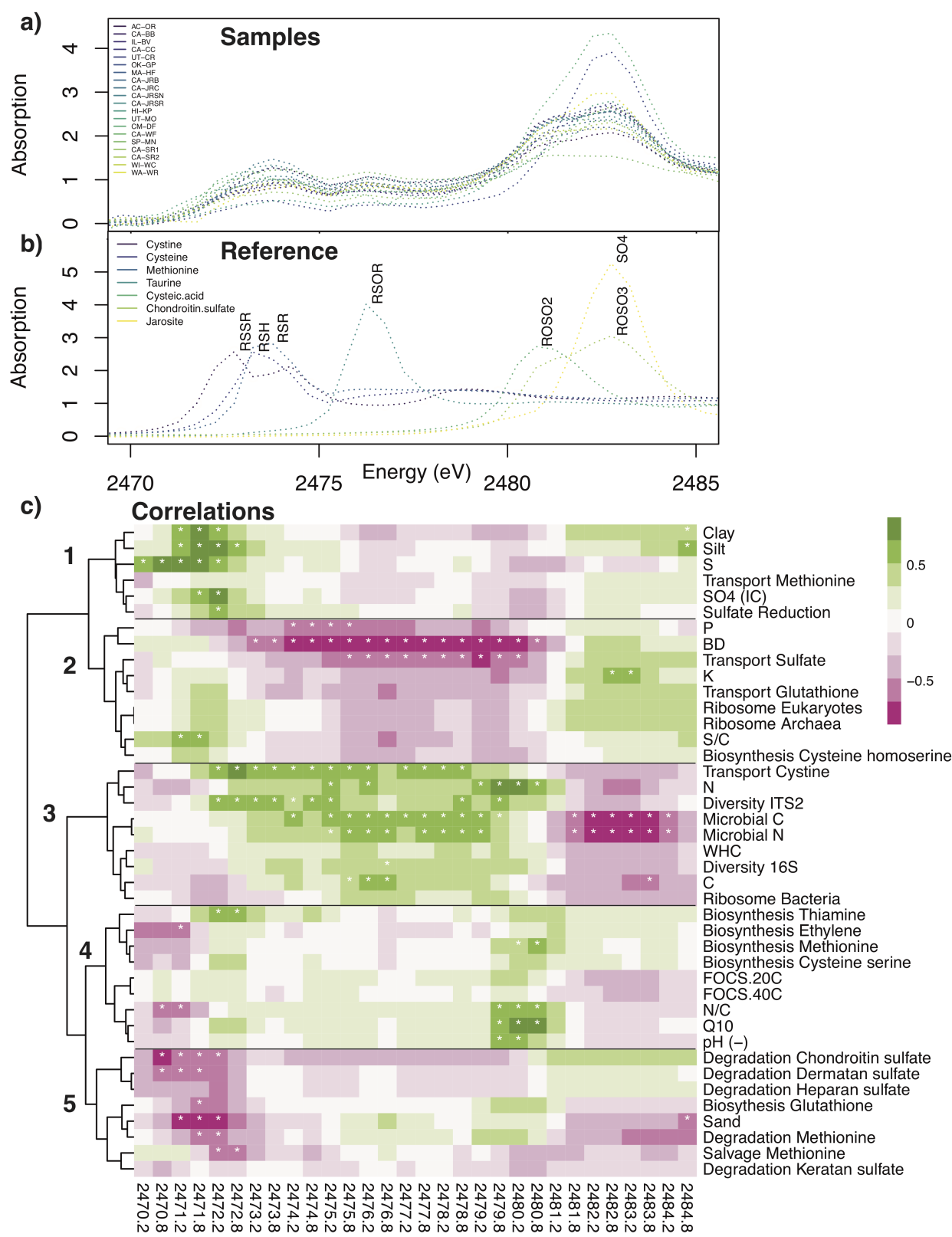

Figure 5. Comparison of site-level trends in XANES absorption spectra with soil physical, chemical, and microbial parameters. S XANES K-edge absorption spectra averaged in $0.5 \mathrm{eV}$ bins (2470 to $2486 \mathrm{eV}$ region) for (a) samples and (b) reference compounds. (c) Correlation coefficient heatmap (Pearson's product moment) between $0.5 \mathrm{eV}$ bins average XANES absorption (columns) and soil chemical, physical, or microbial parameter (rows) and across 19 soil sites (MN-SP soils excluded). Clustering performed using Ward's D2 method (R package pheatmap). Asterisks denote coefficients significantly different from zero $(p$-value $<0.05)$. The negative of the correlation for $\mathrm{pH}$ shown. 
Photochemical degradation was a secondary process to thermal degradation under visible light, though UV-driven photochemical degradation is likely an important OCS production mechanism in the environment. OCS production from a variety of $S$ compounds in aqueous systems depends on UV light (Table 1) and OCS production rates increase with decreasing wavelength $[36,37]$. In soils, OCS production rates were reported to increase in response to full spectrum light in incubations with stable temperature conditions (incandescent bulb; PAR 400-600 nm; $380 \mu \mathrm{mol}\left(\right.$ photons) $\mathrm{m}^{-2} \mathrm{~s}^{-1}$ ) [11]. In the present study, soil OCS production rates tended to increase in response to the light treatment in the visible range (400-700 $\mathrm{nm}$ with two weak peaks below $400 \mathrm{~nm}$ (UV); $580 \mu \mathrm{mol}$ (photons) $\mathrm{m}^{-2} \mathrm{~s}^{-1}$ ), but the response was not significant. The apparent increase in OCS production rates in response to visible light can be attributed to the temperature artifact induced by the incubation lamps (see Section 2.2.3 and [13]). That is, the relative ratio of light/dark OCS production was $2.17 \pm 0.39$ (mean and 95\% confidence intervals) can be explained by the expected temperature-induced ratio of $1.81 \pm 0.08$ determined from our $Q_{10}$ results (Survey 1 ) or $1.70_{-1.70}^{+1.48}$ that was calculated from independent measurements from some Survey 2 soils [10]. In the environment, solar irradiance drives important UV-driven photo-degradation reactions [69]. For example, OCS fluxes (emissions) in an alpine grassland were exponentially related to total incoming solar radiation (305 to $2800 \mathrm{~nm}$ ), but only weakly related to modest changes in soil temperature $\left(\sim 10^{\circ} \mathrm{C}\right)$ measured at $5 \mathrm{~cm}$ depth [5]. It may be difficult to attribute OCS production to either thermal or photo degradation reactions in the environment when solar radiation and temperature are highly correlated. For example, OCS production rates were exponentially related to air temperature at the OK-GP site (soil and senescing wheat material), which may also have been related to solar radiation [7]. We hypothesized that the dominant mechanism for OCS production in soils is abiotic photo-thermal degradation of $S$ compounds. We confirmed that thermal degradation plays a dominant role in soils, but that photochemical degradation driven by visible light is insignificant. UV-driven photo-degradation reactions are likely important in the environment, but the remainder of our discussion focuses on non-photochemical mechanisms of soil OCS production that are most relevant to our results.

\subsubsection{Direct Microbial OCS Production}

Direct microbial production of OCS is likely minor compared to indirect production of OCS through the production of S-containing precursors by microbes. Direct OCS production has been observed in salt marsh environments, presumably mediated by saline microbial communities, which are typically less diverse and differ compositionally from soils [70]. Soil isolates, including common bacteria (e.g., Mycobacteria) and fungi (e.g., Ascomycota) may consume, and in some cases produce, OCS through unknown pathways [16-18]. Microbial OCS production via thiocyanate hydrolase and $\mathrm{CS}_{2}$ hydrolase has been documented [71,72]. In this study, we evaluated thiocyanate hydrolase expressed in soils (see Appendix A) and have recently evaluated carbonic anhydrase gene expression [41]. Two roadblocks limit the conclusions we can draw from these data. Firstly, thiocyanate hydrolase and $\mathrm{CS}_{2}$ hydrolase are enzymes that fall within broader enzyme classes (nitrile hydratase and $\beta$-class of CA, respectively). The distribution of OCS production across the significant genetic diversity within those classes is not known, but is critical for interpretation of genetic data, especially because $\beta$-CA are primarily known to take up (not produce) OCS. Secondly, RNA-based data collected from moist soils should not be expected to reflect microbial activity in soils that were additionally dried for $\sim 45$ days. Our metatranscriptome analysis does indicate that soil microbial communities have the genomic potential for thiocyanate hydrolase and $\mathrm{CS}_{2}$ hydrolase activity, but stronger relationships cannot be inferred. In dry soils, microbial activity is limited by low moisture [42], although extracellular metabolic reactions may proceed with enzymes stabilized by soil particles [73]. In previous work, OCS production rates did not vary significantly between dry and moist soil [10], no temperature optimum (characteristic of enzyme activity) was observed (up to $68^{\circ} \mathrm{C}$ in [8]), and OCS production persists following autoclaving $[11,16]$. Consistent with our expectations, we do not find evidence that direct microbial OCS production pathways contribute significantly to OCS fluxes in soils, though our current 
understanding of the populations and pathways involved in direct microbial OCS production is far from complete.

\subsubsection{Precursors for OCS Production in Soils}

Direct mechanisms connecting soil sulfate and OCS production are unclear, though soils high in sulfate and redox dynamics appear to promote OCS production. When measured by IC, sulfate was a driver of OCS production (Table 6) and was associated with reduced regions in the XANES sulfur spectrum associated with the sulfate reduction pathway (Figure 5c). However, the microbial pathway analysis found that the sulfate reduction pathway was orthogonal to OCS production rates (Figure 4). The role of sulfate was further complicated by inconsistent patterns in between the two analysis methods, IC and XANES (Figure 3), and by weak relationships between OCS and XANES sulfate levels. The relationship between sulfate and OCS production was primarily driven by the tropical soils from Cambodia (CM-WF and CM-DF; Figure 3a), which are seasonally flooded paddy soils (river water) for rice cultivation and are otherwise grazed. These conditions may induce particular $\mathrm{S}$ redox chemistry that is not linearly related to the other soils. In low sulfate soils, OCS production does not appear to be directly or mechanistically coupled to soil sulfate cycling, but connections may become important in soils with high levels of sulfate, potentially depending on redox dynamics.

Biological $S$ assimilation and subsequent production of diverse organic $S$ compounds is the source of a pool of OCS precursors in soil. We found that OCS production (both $F$ and $Q_{10}$ ) was associated with cysteine, methionine, thiamine, and ethylene biosynthesis and cystine transport (Figure 4) and potentially a range of reduced and intermediate $\mathrm{S}$ compounds (Figure 5). Previous work has shown that S-containing amino acids cysteine (R-SH), methionine (R-S-R'), and related S compounds are OCS precursors (Table 1), and cysteine and thiocyanate additions to soil stimulate OCS production [74]. Approximately 11-31\% of organic sulfur in soils is composed of cysteine and methionine (at about a 2:1 ratio), but these are difficult to independently and accurately measure [75]. $\mathrm{S}$ compound interconversions are complex and proceed quickly via biological (e.g., methionine salvage pathway [76]) and abiotic (e.g., cysteine oxidation to cystine [77]) pathways. The derivatives of cysteine and methionine span a broad range of $\mathrm{S}$ oxidation states that absorb energy from highly reduced (e.g., cystine (R-S-S-R'), the disulfide derivative of cysteine) to more intermediate (e.g., methionine sulfone ( $\left.\mathrm{R}-\mathrm{O}-\mathrm{SO}_{2}\right)$, an oxidized form of methionine) XANES spectral regions, consistent with the range of intermediate $\mathrm{S}$ redox states that were associated with OCS production terms (Figure $5 \mathrm{c}$ Cluster 4). If assimilated S compounds are precursors for OCS production, OCS precursors must be steadily produced or stabilized in soil to explain the long-lasting ability of dry soils to emit OCS (e.g., median 45 days for Survey 1). In aqueous systems, OCS precursor pools were finite, but relatively long lived as production rates from natural dissolved organic matter under UV light decreased only slowly over time [33]. Given enough time, OCS precursors may become depleted in dry or sterilized soils, and OCS emissions could cease until rewetting or recolonization. If this mechanism were important, it might help explain why arid-land soils exhibited the lowest OCS production rates (Table 4). Redox fluctuations that drive interconversions between $S$ compounds may play an important role in fostering OCS precursor pools. Previous work has noted increases in OCS production at low redox potentials $[47,78]$, consistent the expected low redox potential of CM soils, although we observed a positive relationship with redox potentials in Survey 2 (Table 6). Considering our results together with previous data, we propose that OCS emissions from soil arise from the production of organic $S$ precursors during the biosynthesis of S-containing amino acids or other central S biomolecules such as thiamine and glutathione. These results are consistent with our hypothesis that plants and microbes may drive OCS production through indirect means. 


\subsection{Proposed OCS Production Mechanism of Coupled Biotic-Abiotic OCS Production from S-Containing Amino Acids}

The results of our study suggest that a coupled abiotic-biotic mechanism drives OCS production in soils. Precursors for OCS emissions are produced in the course of microbial biosynthesis of S-containing amino acids cysteine and methionine and/or other central $\mathrm{S}$ biomolecules such as thiamine and glutathione. Direct precursor molecules may include these specific $S$ compounds or their derivatives with $\mathrm{S}$ oxidation states around $+\mathrm{II}$ or lower. These OCS precursors maybe stabilized in microbial cells or in the soil matrix to facilitate relatively long-lasting OCS production potential from soils. We posit that direct OCS production from these chemical precursors is abiotic, and increases in response to temperature, and potentially light (although the UV light response was not evaluated in this study). This mechanism may be prevalent in both dry and moist soils. Differences in the amount or the availability of these precursors for degradation likely depends on properties of the soil such as total $\mathrm{N}$ content, $\mathrm{C} / \mathrm{N}, \mathrm{pH}$, and $\mathrm{BD}$ either through direct effects or indirectly by affecting microbial activity and $\mathrm{S}$ cycling.

\section{Conclusions}

We have evaluated OCS production rates; their temperature and (visible) light sensitivity; and a wide range of soil chemical, physical, and microbial data for 58 soils collected in two distinct soil surveys. The evaluation revealed consistent patterns between soil $\mathrm{S}$ speciation and microbial S-cycling pathways, which we used to identify key processes driving OCS production, namely thermal degradation of chemical precursors produced as a consequence of microbial biosynthetic $S$ pathways. We identified widespread microbial pathways that may play a role in returning OCS to the atmosphere from terrestrial ecosystems. This work provides mechanistic insight into the sources of OCS from soil that helps complete our understanding of a ubiquitous component of terrestrial OCS and S cycling.

\subsection{Future Research Directions}

Experimental evaluations of the sensitivity of soil OCS emission to UV light are now needed to better resolve the potential influence of solar radiation on OCS production mechanisms in various ecosystems. New efforts are needed to constrain the relationship between OCS production (or consumption) kinetics in microbial strains and genes encoding potentially related enzymes (e.g., thiocyanate and $\mathrm{CS}_{2}$ hydrolase), and those efforts could be paired with quantification of production or consumption rates of those compounds in soils. The importance of plant-derived vs. microbe-derived OCS precursors to ecosystem OCS emissions is needed. These efforts will help outline the importance of land management practices use such as fertilizer addition and management of plant biomass for ecosystem OCS production.

The mechanistic relationships outlined in this paper will be helpful to modelers who aim to account for the contribution of soil OCS emissions in the OCS budget of the Earth's atmosphere. OCS production rates must be constrained to accurately portray the OCS global atmospheric budget and apply OCS as a tracer for carbon cycling. Building from our results, modelers could predict spatial patterns of OCS production from microbial community data and predicted biosynthetic pathways. These data are becoming more prevalent and could be used to estimate activity on large scales [70,79]. Furthermore, maps of estimated OCS production rates and temperature sensitivity coefficients may be derived from relationships with soil edaphic factors (e.g., $\mathrm{pH}, \mathrm{N}$, and $\mathrm{C} / \mathrm{N}$ ) and / or trends with biome to improve model representations of soil OCS fluxes.

\subsection{Outlook}

OCS is the most abundant S-containing gas in the atmosphere, and resolving key components of the atmospheric budget, like soil OCS cycling, is important for understanding the global biogeochemical S cycle. Our results will provide new mechanistic insight into and predictive strategies 
for representing OCS production in soils. We are hopeful that these observations will be used to better represent soil OCS fluxes and improve the use of OCS as a tracer for leaf-level processes related to carbon and water cycling.

Supplementary Materials: The following are available online at http://www.mdpi.com/2571-8789/2/3/37/s1, Figure S1: OCS soil air-gas exchange rates in soils as a function of incubation temperature and exponential fit, Table S1: Site info for soil samples from Surveys 1 and 2. The full data sets and codes for statistical analyses presented in this manuscript are registered at the Open Science Framework at https:/ / osf.io/pm3zt/.

Author Contributions: L.K.M., K.B., J.S., C.Y., J.O., and L.W. conceived and designed the experiments; L.K.M., K.B., J.S., and M.W. performed the experiments; L.K.M., K.B., C.Y., and J.S. analyzed the data; K.B. and J.O. contributed analysis tools; L.K.M. wrote the paper.

Funding: This project was funded in part by the National Science Foundation Atmospheric and Geospace Sciences Postdoctoral Fellowship (no. 1331214) and US Department of Energy (DOE) Joint Genome Institute (JGI) Community Science Program (no. 2033) awarded to L.M. This project received funding from the European Research Council (ERC) starting grant SOLCA under the European Union's Seventh Framework Programme (grant agreement no. 338264), the French Agence Nationale de la Recherche (grant agreement no. ANR-13-BS06-0005-01) and the Institut National de la Recherche Agronomique (INRA) departments EFPA and EA (PhD studentship of Joana Sauze). Work by K.B. was funded by the DOE Office of Science, Office of Biological and Environmental Research through the SLAC National Accelerator Laboratory scientific focus area (contract no. DE-AC02-76SF00515).

Acknowledgments: We thank Paula Welander, Joe Berry, and Scott Fendorf for supporting this project by providing key laboratory space and resources to make this work possible. We thank Ari Kornfield, and Mark Zahniser for sharing technical expertise. We thank Gabriel Kellogg for preliminary data analysis. Soils were collected with the generous support of Max Berkelhammer, Ken Bible, Sebastien Biraud, Nona Ciariello, Róisín Commane, Ingrid Coughlin, Ankur Desai, Pat Dowell, Evan Goldman, Tom Guilderson, Paul Hanson, Marco Keiluweit, Kehaulani Marshall, Amy Meredith, Lisa Meredith, Jesse Miller, Phen Nuon, Bharat Rastogi, Michael Schaefer, Ulli Seibt, Christian von Sperber, Chris Still, Wu Sun, Jonathan Thom, and Peter Vitousek. We are also grateful to all the scientific teams across Europe and Israel that provided their time to collect soils from their local experimental sites for Survey 2 in this study especially Jorge Curiel-Yuste, Alexandria Correia, Jean-Marc Ourcival, Jukka Pumpanen, Huizhong Zhang, Carmen Emmel, Nina Buchmann, Sabina Keller, Irene Lehner, Anders Lindroth, Andreas Ibrom, Jens Schaarup Sorensen, Dan Yakir, Fulin Yang, Michal Helias, Susanne Burri, Penelope Serrano Ortiz, Maria Rosario Moya Jimenez, Jose Luis Vicente, Holger Tulp, Per Marklund, John Marshall, Nils Henriksson, Raquel Lobo de Vale, Lukas Siebicke, Bernard Longdoz, Pascal Courtois, Julian Kammer, Sam Jones, Noelia Saavedra, Katja Klumpp, Steven Wohl, Aurore Kaisermann, and Ana Gutierrez.

Conflicts of Interest: The authors declare no conflict of interest.

\section{Appendix A}

We recovered genes encoding for thiocyanate hydrolase ( $\operatorname{scnC}$ ) from soil metatranscriptomes for half of the soil samples in Survey 1 and evaluated the frequency of assembled $\sin C$ genes per million genes in the transcriptomes (Table A1). We recovered a median of 58 and 25 genes per million using a Pfam search function (nitrile hydratase target) and a BLAST protein $\left(10^{-15} \mathrm{E}\right.$-value) search, respectively (methods in Section 2.3.1). No significant trend was observed between OCS production rates and relative $\sin C$ gene abundance. We did not map reads to putative $\operatorname{scn} C$ genes for further investigation given the limited information regarding how widespread OCS production is within the nitrile hydratase class. $\mathrm{CS}_{2}$ hydrolase is a highly specific $\beta$-D-CA, which we found previously to be predictive in CA activity for OCS in soils at 30\% water holding capacity [48]. Homologues to known $\mathrm{CS}_{2}$ hydrolases were observed in the $\beta$-CA protein tree of genes recovered from that study, but little is known regarding how widespread OCS production instead of uptake could be in this subclade of $\beta$-CA. Without an understanding of the extent to which function (OCS production) aligns with genes in these enzyme classes (nitrile hydratase and $\beta-\mathrm{CA}$ ), our ability to link levels of thiocyanate hydrolase and $\mathrm{CS}_{2}$ hydrolase to OCS production is limited. 
Table A1. Soil metatranscriptome size and thiocyanate hydrolase ( $\operatorname{scn} C)$ recovery statistics using BLAST and Pfam function search for assembled CA and assembled CA weighted per million total genes in genome.

\begin{tabular}{ccccccc}
\hline \multirow{2}{*}{ Site Name } & \multirow{2}{*}{ JGI Project ID } & \multirow{2}{*}{ Genome Size (bp) } & \multicolumn{2}{c}{ Assembled scnC } & \multicolumn{2}{c}{ Assembled scnC Million Genes ${ }^{-\mathbf{1}}$} \\
\cline { 4 - 6 } & & & BLAST & Pfam & BLAST & Pfam \\
\hline CA-CC & 1106757 & $681,529,179$ & 44 & 64 & 40 & 28 \\
WI-WC & 1106758 & $671,257,491$ & 4 & 82 & 52 & 3 \\
OK-GP & 1106759 & $587,647,789$ & 21 & 104 & 73 & 15 \\
CA-SR2 & 1106756 & $521,748,598$ & 91 & 82 & 64 & 71 \\
CA-BB & 1106760 & $303,323,377$ & 33 & 38 & 51 & 44 \\
CA-JRSN & 1106761 & $245,908,234$ & 1 & 40 & 65 & $2^{1}$ \\
HI-KP & 1106762 & $244,931,251$ & 10 & 49 & 81 & 30 \\
CM-DF & 1106763 & $146,941,622$ & 11 & 12 & 33 & $22^{1}$ \\
CA-SR1 & 1106764 & $88,712,635$ & 5 & 16 & $72^{1}$ & $273^{1}$ \\
IL-BV & 1106755 & $65,589,854$ & 43 & 1 & $6^{1}$ & \\
\hline
\end{tabular}

${ }^{1}$ Genomes $<0.1 \mathrm{Gbp}$ or with few recovered genes subject to spurious ratios.

\section{References}

1. Kesselmeier, J.; Teusch, N.; Kuhn, U. Controlling variables for the uptake of atmospheric carbonyl sulfide by soil. Biogeochemistry 1999, 104, 11577-11584. [CrossRef]

2. Whelan, M.E.; Lennartz, S.T.; Gimeno, T.E.; Wehr, R.; Wohlfahrt, G.; Wang, Y.; Kooijmans, L.M.J.; Hilton, T.W.; Belviso, S.; Peylin, P.; et al. Reviews and Syntheses: Carbonyl Sulfide as a Multi-scale Tracer for Carbon and Water Cycles. Biogeosci. Discuss. 2017, 1-97. [CrossRef]

3. Commane, R.; Meredith, L.K.; Baker, I.T.; Berry, J.A.; Munger, J.W.; Montzka, S.A.; Templer, P.H.; Juice, S.M.; Zahniser, M.S.; Wofsy, S.C. Seasonal fluxes of carbonyl sulfide in a midlatitude forest. Proc. Natl. Acad. Sci. USA 2015, 112, 14162-14167. [CrossRef] [PubMed]

4. Billesbach, D.P.; Berry, J.A.; Seibt, U.; Maseyk, K.; Torn, M.S.; Fischer, M.L.; Abu-Naser, M.; Campbell, J.E. Growing season eddy covariance measurements of carbonyl sulfide and $\mathrm{CO}_{2}$ fluxes: $\mathrm{COS}$ and $\mathrm{CO}_{2}$ relationships in Southern Great Plains winter wheat. Agric. For. Meteorol. 2014, 184, 48-55. [CrossRef]

5. Kitz, F.; Gerdel, K.; Hammerle, A.; Laterza, T.; Spielmann, F.M.; Wohlfahrt, G. In situ soil COS exchange of a temperate mountain grassland under simulated drought. Oecologia 2017, 183, 851-860. [CrossRef] [PubMed]

6. Sun, W.; Maseyk, K.; Lett, C.; Seibt, U. Litter dominates surface fluxes of carbonyl sulfide in a Californian oak woodland. J. Geophys. Res. Biogeosci. 2016, 121, 438-450. [CrossRef]

7. Maseyk, K.; Berry, J.A.; Billesbach, D.; Campbell, J.E.; Torn, M.S.; Zahniser, M.; Seibt, U. Sources and sinks of carbonyl sulfide in an agricultural field in the Southern Great Plains. Proc. Natl. Acad. Sci. USA 2014, 111, 9064-9069. [CrossRef] [PubMed]

8. Whelan, M.E.; Hilton, T.W.; Berry, J.A.; Berkelhammer, M.; Desai, A.R.; Campbell, J.E. Carbonyl sulfide exchange in soils for better estimates of ecosystem carbon uptake. Atmos. Chem. Phys. 2016, 16, 3711-3726. [CrossRef]

9. Bunk, R.; Behrendt, T.; Yi, Z.; Andreae, M.O.; Kesselmeier, J. Exchange of carbonyl sulfide (OCS) between soils and atmosphere under various $\mathrm{CO}_{2}$ concentrations. J. Geophys. Res. Biogeosci. 2017, 122, 1343-1358. [CrossRef]

10. Kaisermann, A.; Ogée, J.; Sauze, J.; Wohl, S.; Jones, S.P.; Gutierrez, A.; Wingate, L. Disentangling the rates of carbonyl sulphide (COS) production and consumption and their dependency with soil properties across biomes and land use types. Atmos. Chem. Phys. Discuss. 2018, 1-27. [CrossRef]

11. Whelan, M.E.; Rhew, R.C. Carbonyl sulfide produced by abiotic thermal and photodegradation of soil organic matter from wheat field substrate. J. Geophys. Res. Biogeosci. 2015, 120, 54-62. [CrossRef]

12. Fried, A.; Klinger, L.F.; Erickson, D.J. Atmospheric carbonyl sulfide exchange in bog microcosms. Geophys. Res. Lett. 1993, 20, 129-132. [CrossRef] 
13. Gimeno, T.E.; Ogée, J.; Royles, J.; Gibon, Y.; West, J.B.; Burlett, R.; Jones, S.P.; Sauze, J.; Wohl, S.; Benard, C.; et al. Bryophyte gas-exchange dynamics along varying hydration status reveal a significant carbonyl sulphide (COS) sink in the dark and COS source in the light. New Phytol. 2017, 215, 965-976. [CrossRef] [PubMed]

14. Berry, J.; Wolf, A.; Campbell, J.E.; Baker, I.; Blake, N.; Blake, D.; Denning, A.S.; Kawa, S.R.; Montzka, S.A.; Seibt, U.; et al. A coupled model of the global cycles of carbonyl sulfide and $\mathrm{CO}_{2}$ : A possible new window on the carbon cycle. J. Geophys. Res. Biogeosci. 2013, 118, 842-852. [CrossRef]

15. Sauze, J.; Ogée, J.; Maron, P.A.; Crouzet, O.; Nowak, V.; Wohl, S.; Kaisermann, A.; Jones, S.P.; Wingate, L. The interaction of soil phototrophs and fungi with $\mathrm{pH}$ and their impact on soil $\mathrm{CO}_{2}, \mathrm{CO}^{18} \mathrm{O}$ and OCS exchange. Soil Biol. Biochem. 2017, 115, 371-382. [CrossRef] [PubMed]

16. Kato, H.; Saito, M.; Nagahata, Y.; Katayama, Y. Degradation of ambient carbonyl sulfide by Mycobacterium spp. in soil. Microbiology 2008, 154, 249-255. [CrossRef] [PubMed]

17. Masaki, Y.; Ozawa, R.; Kageyama, K.; Katayama, Y. Degradation and emission of carbonyl sulfide, an atmospheric trace gas, by fungi isolated from forest soil. FEMS Microbiol. Lett. 2016, 363. [CrossRef] [PubMed]

18. Ogawa, T.; Kato, H.; Higashide, M.; Nishimiya, M.; Katayama, Y. Degradation of carbonyl sulfide by Actinomycetes and detection of clade D of $\beta$-class carbonic anhydrase. FEMS Microbiol. Lett. 2016, 363, fnw223. [CrossRef] [PubMed]

19. Smith, N.A.; Kelly, D.P. Oxidation of Carbon Disulphide as the Sole Source of Energy for the Autotrophic Growth of Thiobacillus thioparus Strain TK-m. Microbiology 1988, 134, 3041-3048. [CrossRef]

20. Sorokin, D.Y.; Abbas, B.; van Zessen, E.; Muyzer, G. Isolation and characterization of an obligately chemolithoautotrophic Halothiobacillus strain capable of growth on thiocyanate as an energy source. FEMS Microbiol. Lett. 2014, 354, 69-74. [CrossRef] [PubMed]

21. Ogawa, T.; Noguchi, K.; Saito, M.; Nagahata, Y.; Kato, H.; Ohtaki, A.; Nakayama, H.; Dohmae, N.; Matsushita, Y.; Odaka, M.; et al. Carbonyl Sulfide Hydrolase from Thiobacillus thioparus Strain THI115 Is One of the $\beta$-Carbonic Anhydrase Family Enzymes. J. Am. Chem. Soc. 2013, 135, 3818-3825. [CrossRef] [PubMed]

22. Bezsudnova, E.Y.; Sorokin, D.Y.; Tikhonova, T.V.; Popov, V.O. Thiocyanate hydrolase, the primary enzyme initiating thiocyanate degradation in the novel obligately chemolithoautotrophic halophilic sulfur-oxidizing bacterium Thiohalophilus thiocyanoxidans. Biochim. Biophys. Acta Proteins Proteom. 2007, 1774, 1563-1570. [CrossRef] [PubMed]

23. Hussain, A.; Ogawa, T.; Saito, M.; Sekine, T.; Nameki, M.; Matsushita, Y.; Hayashi, T.; Katayama, Y. Cloning and expression of a gene encoding a novel thermostable thiocyanate-degrading enzyme from a mesophilic alphaproteobacteria strain THI201. Microbiology 2013, 159, 2294-2302. [CrossRef] [PubMed]

24. Katayama, Y.; Narahara, Y.; Inoue, Y.; Amano, F.; Kanagawa, T.; Kuraishi, H. A thiocyanate hydrolase of Thiobacillus thioparus. A novel enzyme catalyzing the formation of carbonyl sulfide from thiocyanate. J. Biol. Chem. 1992, 267, 9170-9175. [PubMed]

25. Yamasaki, M.; Matsushita, Y.; Nyunoya, H.; Katayama, Y.; Namura, M. Genetic and Immunochemical Characterization of Thiocyanate-Degrading Bacteria in Lake Water Genetic and Immunochemical Characterization of Thiocyanate-Degrading Bacteria in Lake Water. Appl. Environ. Microbiol. 2002, 68, 942-946. [CrossRef] [PubMed]

26. Welte, C.U.; Rosengarten, J.F.; de Graaf, R.M.; Jetten, M.S.M. SaxA-Mediated Isothiocyanate Metabolism in Phytopathogenic Pectobacteria. Appl. Environ. Microbiol. 2016, 82, 2372-2379. [CrossRef] [PubMed]

27. Churka Blum, S.; Lehmann, J.; Solomon, D.; Caires, E.F.; Alleoni, L.R.F. Sulfur forms in organic substrates affecting S mineralization in soil. Geoderma 2013, 200-201, 156-164. [CrossRef]

28. Kertesz, M.A.; Mirleau, P. The role of soil microbes in plant sulphur nutrition. J. Exp. Bot. 2004, 55, 1939-1945. [CrossRef] [PubMed]

29. Minami, K.; Fukushi, S. Volatilization of carbonyl sulfide from paddy soils treated with sulfur-containing substances. Soil Sci. Plant Nutr. 1981, 27, 339-345. [CrossRef]

30. Lehmann, S.; Conrad, R. Characteristics of Turnover of Carbonyl Sulfide in 4 Different Soils. J. Atmos. Chem. 1996, 23, 193-207. [CrossRef]

31. Hanschen, F.S.; Lamy, E.; Schreiner, M.; Rohn, S. Reactivity and Stability of Glucosinolates and Their Breakdown Products in Foods. Angew. Chem. Int. Ed. 2014, 53, 11430-11450. [CrossRef] [PubMed] 
32. Steiger, A.K.; Zhao, Y.; Pluth, M.D. Emerging Roles of Carbonyl Sulfide in Chemical Biology: Sulfide Transporter or Gasotransmitter? Antioxid. Redox Signal. 2017. [CrossRef] [PubMed]

33. Ferek, R.J.; Andreae, M.O. Photochemical production of carbonyl sulphide in marine surface waters. Nature 1984, 307, 148-150. [CrossRef]

34. Flöck, O.R.; Andreae, M.O.; Dräger, M. Environmentally relevant precursors of carbonyl sulfide in aquatic systems. Mar. Chem. 1997, 59, 71-85. [CrossRef]

35. Kelly, D.P.; Wood, A.P.; Jordan, S.L.; Padden, A.N.; Gorlenko, V.M.; Dubinina, G.A. Biological production and consumption of gaseous organic sulphur compounds. Biochem. Soc. Trans. 1994, 22, 1011-1015. [CrossRef] [PubMed]

36. Zepp, R.G.; Andreae, M.O. Factors affecting the photochemical production of carbonyl sulfide in seawater. Geophys. Res. Lett. 1994, 21, 2813-2816. [CrossRef]

37. Du, Q.; Mu, Y.; Zhang, C.; Liu, J.; Zhang, Y.; Liu, C. Photochemical production of carbonyl sulfide, carbon disulfide and dimethyl sulfide in a lake water. J. Environ. Sci. 2017, 51, 146-156. [CrossRef] [PubMed]

38. Geng, C.; Mu, Y. Carbonyl sulfide and dimethyl sulfide exchange between trees and the atmosphere. Atmos. Environ. 2006, 40, 1373-1383. [CrossRef]

39. Zhang, L.; Walsh, R.S.; Cutter, G.A. Estuarine cycling of carbonyl sulfide: Production and sea-air flux. Mar. Chem. 1998, 61, 127-142. [CrossRef]

40. Pos, W.H.; Riemer, D.D.; Zika, R.G. Carbonyl sulfide (OCS) and carbon monoxide (CO) in natural waters: Evidence of a coupled production pathway. Mar. Chem. 1998, 62, 89-101. [CrossRef]

41. Meredith, L.K.; Ogée, J.; Boye, K.; Singer, E.; Wingate, L.; von Sperber, C.; Sengupta, A.; Whelan, M.; Pang, E.; Keiluweit, M.; et al. Soil exchange rates of $\mathrm{COS}$ and $\mathrm{CO}^{18} \mathrm{O}$ shift with the diversity of microbial communities and their carbonic anhydrase enzymes. ISME J. 2018, in press.

42. Tecon, R.; Or, D. Biophysical processes supporting the diversity of microbial life in soil. FEMS Microbiol. Rev. 2017, 41, 599-623. [CrossRef] [PubMed]

43. Hobbie, S. Chloroform Fumigation Direct Extraction (CFDE) Protocol for Microbial Biomass Carbon and Nitrogen. Allison Lab Protoc. 2008, 4.

44. Brookes, P.C.; Landman, A.; Pruden, G.; Jenkinson, D.S. Chloroform fumigation and the release of soil nitrogen: A rapid direct extraction method to measure microbial biomass nitrogen in soil. Soil Biol. Biochem. 1985, 17, 837-842. [CrossRef]

45. Vance, E.D.; Brookes, P.C.; Jenkinson, D.S. Microbial biomass measurements in forest soils: The use of the chloroform fumigation-incubation method in strongly acid soils. Soil Biol. Biochem. 1987, 19, 697-702. [CrossRef]

46. Kooijmans, L.M.J.; Uitslag, N.A.M.; Zahniser, M.S.; Nelson, D.D.; Montzka, S.A.; Chen, H. Continuous and high precision atmospheric concentration measurements of $\mathrm{COS}, \mathrm{CO}_{2}, \mathrm{CO}$ and $\mathrm{H}_{2} \mathrm{O}$ using a quantum cascade laser spectrometer (QCLS). Atmos. Meas. Tech. Discuss. 2016, 9, 5293-5314. [CrossRef]

47. Ogée, J.; Sauze, J.; Kesselmeier, J.; Genty, B.; Van Diest, H.; Launois, T.; Wingate, L. A new mechanistic framework to predict OCS fluxes from soils. Biogeosciences 2016, 13, 2221-2240. [CrossRef]

48. Fierer, N.; Schimel, J.P. Effects of drying-rewetting frequency on soil carbon and nitrogen transformations. Soil Biol. Biochem. 2002, 34, 777-787. [CrossRef]

49. Di Stefano, C.; Ferro, V.; Mirabile, S. Comparison between grain-size analyses using laser diffraction and sedimentation methods. Biosyst. Eng. 2010, 106, 205-215. [CrossRef]

50. Harris, I.; Jones, P.D.; Osborn, T.J.; Lister, D.H. Updated high-resolution grids of monthly climatic observations-The CRU TS3.10 Dataset. Int. J. Climatol. 2014, 34, 623-642. [CrossRef]

51. Jalilehvand, F. Sulfur: Not a "silent" element any more. Chem. Soc. Rev. 2006, 35, 1256-1268. [CrossRef] [PubMed]

52. Ravel, B.; Newville, M. ATHENA, ARTEMIS, HEPHAESTUS: Data analysis for X-ray absorption spectroscopy using IFEFFIT. J. Synchrotron Radiat. 2005, 12, 537-541. [CrossRef] [PubMed]

53. Beck, T.; Joergensen, R.G.; Kandeler, E.; Makeshin, E.; Nuss, E.; Oberholzer, H.R.; Scheu, S. An inter-laboratory comparison of ten different ways of measuring soil microbial biomass C. Soil Biol. Biochem. 1997, 29, 1023-1032. [CrossRef]

54. Ward, T. BugBase predicts organism-level microbiome phenotypes. bioRxiv 2017, 1-36. [CrossRef]

55. Kanehisa, M.; Furumichi, M.; Tanabe, M.; Sato, Y.; Morishima, K. KEGG: New perspectives on genomes, pathways, diseases and drugs. Nucleic Acids Res. 2017, 45, D353-D361. [CrossRef] [PubMed] 
56. Kanehisa, M.; Sato, Y.; Kawashima, M.; Furumichi, M.; Tanabe, M. KEGG as a reference resource for gene and protein annotation. Nucleic Acids Res. 2016, 44, D457-D462. [CrossRef] [PubMed]

57. Ogata, H.; Goto, S.; Sato, K.; Fujibuchi, W.; Bono, H.; Kanehisa, M. KEGG: Kyoto encyclopedia of genes and genomes. Nucleic Acids Res. 1999, 27, 29-34. [CrossRef] [PubMed]

58. Chen, I.M.A.; Markowitz, V.M.; Chu, K.; Palaniappan, K.; Szeto, E.; Pillay, M.; Ratner, A.; Huang, J.; Andersen, E.; Huntemann, M.; et al. IMG/M: Integrated genome and metagenome comparative data analysis system. Nucleic Acids Res. 2017, 45, D507-D516. [CrossRef] [PubMed]

59. Wattam, A.R.; Abraham, D.; Dalay, O.; Disz, T.L.; Driscoll, T.; Gabbard, J.L.; Gillespie, J.J.; Gough, R.; Hix, D.; Kenyon, R.; et al. PATRIC, the bacterial bioinformatics database and analysis resource. Nucleic Acids Res. 2014, 42, D581-D591. [CrossRef] [PubMed]

60. Langille, M.G.I.; Zaneveld, J.; Caporaso, J.G.; McDonald, D.; Knights, D.; Reyes, J.A.; Clemente, J.C.; Burkepile, D.E.; Vega Thurber, R.L.; Knight, R.; et al. Predictive functional profiling of microbial communities using 16S rRNA marker gene sequences. Nat. Biotechnol. 2013, 31, 814-821. [CrossRef] [PubMed]

61. Katayama, Y.; Matsushita, Y.; Kaneko, M.; Kondo, M.; Mizuno, T.; Nyunoya, H. Cloning of genes coding for the three subunits of thiocyanate hydrolase of Thiobacillus thioparus THI 115 and their evolutionary relationships to nitrile hydratase. J. Bacteriol. 1998, 180, 2583-2589. [PubMed]

62. Abdi, H. Partial least squares regression and projection on latent structure regression (PLS Regression). Wiley Interdiscip. Rev. Comput. Stat. 2010, 2, 97-106. [CrossRef]

63. Carrascal, L.M.; Galván, I.; Gordo, O. Partial least squares regression as an alternative to current regression methods used in ecology. Oikos 2009, 118, 681-690. [CrossRef]

64. Aitchison, J. The Statistical Analysis of Compositional Data, Monographs on Statistics and Applied Probability; Chapman and Hall: London, UK, 1986.

65. Wehr, R.; Saleska, S.R. The long-solved problem of the best-fit straight line: Application to isotopic mixing lines. Biogeosciences 2017, 14, 17-29. [CrossRef]

66. Manceau, A.; Nagy, K.L. Quantitative analysis of sulfur functional groups in natural organic matter by XANES spectroscopy. Geochim. Cosmochim. Acta 2012, 99, 206-223. [CrossRef]

67. Ma, J.; Wang, Z.-Y.; Stevenson, B.A.; Zheng, X.-J.; Li, Y. An inorganic $\mathrm{CO}_{2}$ diffusion and dissolution process explains negative $\mathrm{CO}_{2}$ fluxes in saline/alkaline soils. Sci. Rep. 2013, 3, 2025. [CrossRef] [PubMed]

68. Saito, M.; Honna, T.; Kanagawa, T.; Katayama, Y. Microbial Degradation of Carbonyl Sulfide in Soils. Microbes Environ. 2002, 17, 32-38. [CrossRef]

69. Baker, N.R.; Allison, S.D.; Frey, S.D. Ultraviolet photodegradation facilitates microbial litter decomposition in a Mediterranean climate. Ecology 2015, 96, 1994-2003. [CrossRef] [PubMed]

70. Thompson, L.R.; Sanders, J.G.; McDonald, D.; Amir, A.; Ladau, J.; Locey, K.J.; Prill, R.J.; Tripathi, A.; Gibbons, S.M.; Ackermann, G.; et al. A communal catalogue reveals Earth's multiscale microbial diversity. Nature 2017, 551, 457-463. [CrossRef] [PubMed]

71. Katayama, Y.; Kanagawa, T.; Kuraishi, H. Emission of Carbonyl Sulfide by Thiobacillus-Thioparus Grown with Thiocyanate in Pure and Mixed Cultures. FEMS Microbiol. Lett. 1993, 114, 223-228. [CrossRef]

72. Smeulders, M.J.; Pol, A.; Venselaar, H.; Barends, T.R.M.; Hermans, J.; Jetten, M.S.M.; Op den Camp, H.J.M. Bacterial CS2 hydrolases from Acidithiobacillus thiooxidans strains are homologous to the archaeal catenane CS2 hydrolase. J. Bacteriol. 2013, 195, 4046-4056. [CrossRef] [PubMed]

73. Wang, B.; Lerdau, M.; He, Y. Widespread production of nonmicrobial greenhouse gases in soils. Glob. Chang. Biol. 2017, 23, 4472-4482. [CrossRef] [PubMed]

74. Minami, K.; Fukushi, S. Detection of carbonyl sulfide among gases produced by the decomposition of cystine in paddy soils. Soil Sci. Plant Nutr. 1981, 27, 105-109. [CrossRef]

75. Morra, M.J.; Dick, W.A. Production of Thiocysteine (Sulfide) in Cysteine Amended Soils. Soil Sci. Soc. Am. J. 1985, 49, 882-886. [CrossRef]

76. Sekowska, A.; Dénervaud, V.; Ashida, H.; Michoud, K.; Haas, D.; Yokota, A.; Danchin, A. Bacterial variations on the methionine salvage pathway. BMC Microbiol. 2004, 4, 1-17. [CrossRef] [PubMed]

77. Freney, J.R. Aerobic transformation of cysteine to sulphate in soil. Nature 1958, 182, 1318-1319. [CrossRef] 
78. Devai, I.; DeLaune, R.D. Formation of volatile sulfur compounds in salt marsh sediment as influenced by soil redox condition. Org. Geochem. 1995, 23, 283-287. [CrossRef]

79. Delgado-Baquerizo, M.; Oliverio, A.M.; Brewer, T.E.; Benavent-González, A.; Eldridge, D.J.; Bardgett, R.D.; Maestre, F.T.; Singh, B.K.; Fierer, N. A global atlas of the dominant bacteria found in soil. Science 2018, 359, 320-325. [CrossRef] [PubMed] 